UNIVERSIDADE DE SÃO PAULO

ESCOLA DE ENGENHARIA DE SÃO CARLOS - FACULDADE DE MEDICINA DE RIBEIRÃO PRETO - INSTITUTO DE QUÍMICA DE SÃO CARLOS

\title{
MATRIZES TRIDIMENSIONAIS DE COLÁGENO ANIÔNICO:ELASTINA COMO SUPORTE PARA RECONSTRUÇÃO DE TECIDOS MOLES: UM ESTUDO DA INTEGRAÇÃO MATRIZ:TECIDO
}

\section{Diderot Rodrigues Parreira}

Dissertação apresentada à Pós Graduação da Interunidades em Bioengenharia da Universidade de São Paulo para obtenção do título de Mestre em Bioengenharia

Orientador: Prof. Dr. Gilberto Goissis

São Carlos - SP 
Ficha cata lográfic a preparada pela Seção de Tratamento da Informação do Serviço de Biblioteca - EESC/USP

\begin{tabular}{|l} 
Parreira, Diderot Rodrigues \\
Matrizes tridimensionais de colágeno aniônico:elastina \\
como suporte para reconstrução de tecidos moles : um \\
estudo da integração matriz:tecido / Diderot Rodrigues \\
Parreira. -- São Carlos, 2004. \\
Dissertação (Mestrado) -- Escola de Engenharia de são \\
Carlos/Faculdade de Medicina de Ribeirão preto/Instituto \\
de Química de São Carlos-Universidade de São Paulo, 2004. \\
Área Interunidades: Bioengenharia. \\
Orientador: Prof. Dr. Gilberto Goissis. \\
1. Implante. 2. Colágeno aniônico. 3. Pericárdio \\
bovino. Matrizes tridimensionais. 5. Tecido \\
conjuntivo. 6. Biocompatibilidade. 7. Engenharia de \\
tecidos.
\end{tabular}




\section{DEDICATÓRIA}

\section{AOS MEUS PAIS}

A vocês que sempre renunciaram os seus desejos próprios em favor dos meus e dos meus irmãos. Vocês fizeram de meus sonhos os seus, sem medir esforços para realizá-los. Iluminaram meu caminho com Amor e dedicação. "Obrigado" é uma palavra que fica pequena por toda gratidão que tenho por vocês. Deus me abençoou com vocês ao meu lado. AMO VOCÊS, "PAPAI e MAMÃE"!

\section{A DEUS}

Pela minha vida, por todas as graças concedidas e por SEMPRE guiar meus caminhos. Obrigado por ter colocado em meu caminho todas essas pessoas maravilhosas que me apoiaram e me ajudaram neste trabalho.

\section{AO PROFESSOR GILBERTO GOISSIS}

Por ter me acolhido como um filho e ensinado tudo o que sei hoje sobre pesquisa. Obrigado pela ajuda, apoio, paciência e amizade durante todo este tempo que trabalhamos juntos.

\section{À PROFESSORA SUELI SUZIGAN}

Pela amizade, paciência e pelo seu empenho em me tornar um pesquisador. 


\section{AGRADECIMENTOS}

- Aos meus irmãos Darlan e Daladié pela ajuda, carinho e amizade durante o decorrer de minha vida.

- Aos técnicos do Laboratório de Bioquímica Ezer Biazin e Glauco D. Broch, pelo auxílio técnico e pela amizade.

- Ao Sr Luiz Bizutti pela amizade e colaboração nas cirurgias realizadas nos ratos.

- À Virgínia C. A. Martins pela amizade e ajuda na conclusão deste trabalho.

- Ao pessoal do Laboratório de Biomateriais, Márcio e Fátima pela ajuda sempre de última hora com os computadores.

- Aos professores Sergio Yoshioka e Ana Maria de Guzzi Plepis pela amizade e apoio.

- Ao professor José Victor Maniglia pelo apoio à pesquisa e pelo crédito em meu potencial profissional.

- À secretária Claudia pelos serviços prestados, gentileza, amizade e dedicação.

- Ao professor João Vicente de Paiva pelo auxílio quanto ao uso do biotério da FAMERP.

- À FAPESP pela bolsa e pelo apoio concedidos às minhas pesquisas.

- À Braile Biomédica pelo fornecimento dos pericárdios bovinos utilizados neste trabalho.

- Enfim, a todos que de alguma forma colaboraram para a realização deste trabalho, os mais sinceros agradecimentos. 


\section{SUMÁRIO}

RESUMO

ABSTRACT

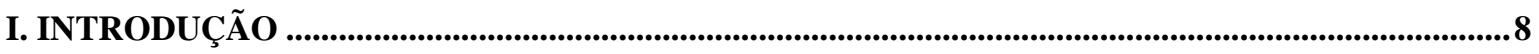

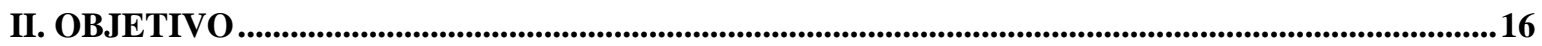

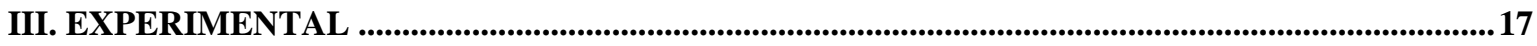

III.1. Hidrólise Seletiva de Grupos Carboxamidas da Matriz Colagênica ..............................................17

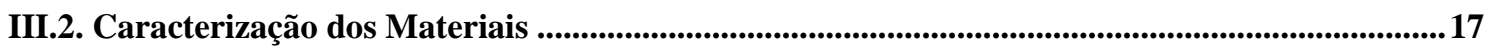

III.2.1. Calorimetria exploratória diferencial ................................................................................17

III.2.2. Microscopia eletrônica de varredura (MEV).................................................................18

III.2.3. Microscopia eletrônica de transmissão (MET) .............................................................. 18

III.3. Implante em subcutâneo de rato............................................................................................................18

III.3.1. Microscopia de luz .............................................................................................................21

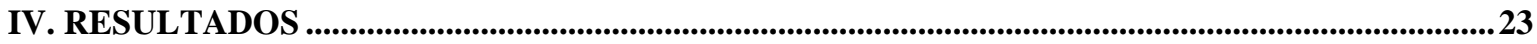

IV.1. Avaliação da estrutura por estabilidade térmica ................................................................................23

IV.2. Microscopia eletrônica de varredura ………….......................................................................................25

IV.3. Microscopia eletrônica de transmissão.....................................................................................................26

IV.4. Histologia dos Explantes.........................................................................................................................2

IV.4.1. Explantes após 14 Dias............................................................................................................27

IV.4.2. Explantes após 60 Dias................................................................................................... 32

IV.4.3. Explantes após 120 Dias...................................................................................................34

IV.4.4. Explantes após 180 Dias.............................................................................................39 


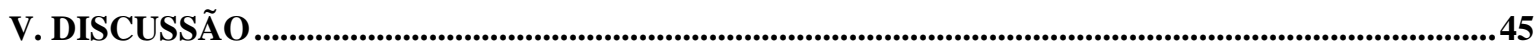

V.1. Biocompatibilidade ....................................................................................................45

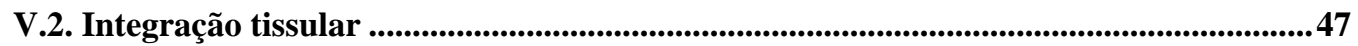

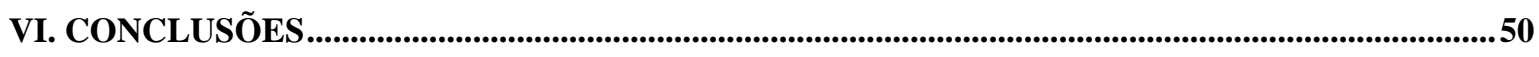

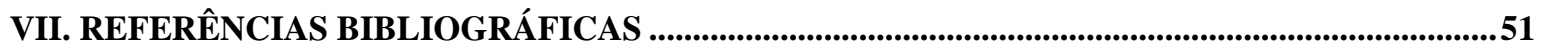




\section{ABSTRACT}

PARREIRA, D.R. (2004). Tridimentional collagen:elastin matrices as scaffold for soft tissue reconstruction: matrix:tissue integration study. M.Sc. Dissertation Interunidades em Bioengenharia, Universidade de São Paulo, São Carlos, 2004

This work studied the integration of acellular polyanionic collagen:elastin matrices derived of bovine pericardium (BP) with variable negative charge .

Negative charges were introduced in the material by selective hydrolisis of carboxamide side chain groups from Asn and Gln present in the primary structure of the protein. Hydrolized materials after 24 and 48 hours of treatment, respectively with $46 \pm$ and $87 \pm$ extra negative charges, were studied. Implants were placed in the subcutaneous of rats for periods of 14, 60, 120 and 180 days. Materials were characterized by differential scanning calorimetry, SEM and TEM, and explants analysed by optical microscopy (H.E., Masson tricromic and Verhoeff stains).

The purpose of this work was to evaluate the use of modified collagen matrices for soft tissue reconstruction.

Differently from native tissue (BP), the biological response of polyanionic collagen:elastin matrices after 14 days from implantation was characterized by a progressive decrease in fibrosis, but most important, no characteristic cells of a chronic inflammatory response were observed. After 180 days, most of the implants were integrated to the implant region.

The results suggest that acellular collagen:elastin matrices prepared by devitalization of natural tissue due to their high degree of biocompatibility and integration may be potentially useful as a scaffold for soft tissue reconstruction.

Keywords: implant; anionic collagen; bovine pericardium; tridimentional matrices; connective tissue; biocompatibility; tissue enginnering. 


\section{RESUMO}

PARREIRA, D.R. (2004). Matrizes tridimensionais de colágeno:elastina como suporte para a reconstrução de tecidos moles: um estudo da integração matriz:tecido. Dissertação de Mestrado - Interunidades em Bioengenharia, Universidade de São Paulo, São Carlos, 2004

Este trabalho visou estudar a integração de implantes de colágeno aniônico:elastina obtidos a partir de pericárdio bovino acelularizado e com densidade de carga negativa variável.

As cargas negativas foram introduzidas na forma de grupos carboxílicos, por hidrólise seletiva e controlada de grupos carboxamidas de asparagina e glutamina contidos na estrutura primária da proteína. Foram estudados materiais hidrolisados por 24 e 48 horas de tratamento correspondendo, respectivamente, a $46 \pm$ e $87 \pm$ cargas negativas adicionais em relação ao colágeno nativo. Os implantes foram introduzidos no subcutâneo de rato por tempos de 14, 60, 120 e 180 dias. Os materiais foram caracterizados por análise térmica, microscopia eletrônica de varredura e de transmissão, e os explantes avaliados por microscopia de luz (colorações de Hematoxilina:Eosina, tricrômico de Masson e Verhoeff).

O objetivo foi avaliar o uso de matrizes com colágeno modificado para a reconstrução de tecidos moles.

Diferentemente do tecido nativo (pericárdio bovino), a resposta biológica de matrizes de colágeno:elastina polianiônica após 14 dias do implante foi caracterizada por uma progressiva redução na fibrose, porém mais importante, não foram observadas células características de resposta inflamatória crônica, particularmente nos materiais tratados quimicamente. Após 180 dias, a maioria dos implantes estavam integrados à região implantada.Tais resultados sugerem que matrizes acelulares de colágeno:elastina preparadas pela desvitalização de tecido natural podem ser suportes bastante úteis para a reconstrução de tecidos moles, devido ao seu elevado grau de biocompatibilidade e integração.

Palavras- chave: implante; colágeno aniônico; pericárdio bovino; matrizes tridimensionais; tecido conjuntivo; biocompatibilidade; engenharia de tecidos. 


\section{INTRODUÇÃO}

A perda ou a falência de um órgão ou tecido, um dos problemas de saúde mais severos para o homem (1), tem consumido, nos EUA, aproximadamente a metade do total de gastos com a saúde (2). A indicação padrão, que é o transplante de tecidos ou órgãos, é limitada severamente pela quantidade de doadores e esterilidade do material. Outras terapias disponíveis incluem a reconstrução cirúrgica (por exemplo, coração), terapias com drogas (insulina), próteses sintéticas (próteses vasculares) e os dispositivos biomédicos (dialisadores renais). Embora estas não sejam limitadas pelo suprimento, apresentam duas grandes desvantagens: não repõem todas as funções do tecido lesado e, com uma freqüência maior que a desejável, fracassam após tempos variáveis de uso (2). Estas tecnologias, em sua grande maioria, evoluíram em função do desenvolvimento dos biomateriais, que dentro da sua evolução natural deu origem a uma nova área, a engenharia de tecidos (3). Esta, por sua vez, está fundamentada no comportamento de células isoladas que, quando colocadas em "meio apropriado", se organizam "in vitro" em estruturas funcionalmente similares ao tecido original (4). Este "meio apropriado", denominado de matriz extracelular (MEC), é de origem sintética ou natural, de natureza tridimensional e biodegradável, servindo como suporte, "in vitro" ou "in vivo", para o desenvolvimento de um novo tecido destinado à restauração de funções biológicas naturais (1-3).

Materiais utilizados para este fim são denominados de biomateriais e uma de suas definições é a de "ser uma substância ou combinação entre duas ou mais substâncias, de natureza sintética ou natural, que podem ser utilizadas por um período de tempo, para melhorar, aumentar ou substituir, parcial ou inteiramente tecidos ou órgãos” (5). São exemplos, os materiais que substituem ou induzem o crescimento de tecido ósseo, cartilagens, peles, vasos, válvulas cardíacas e outros tecidos (6). A Figura 1 traz um esquema representativo das funções biológicas que podem ser substituídas por biomateriais. 


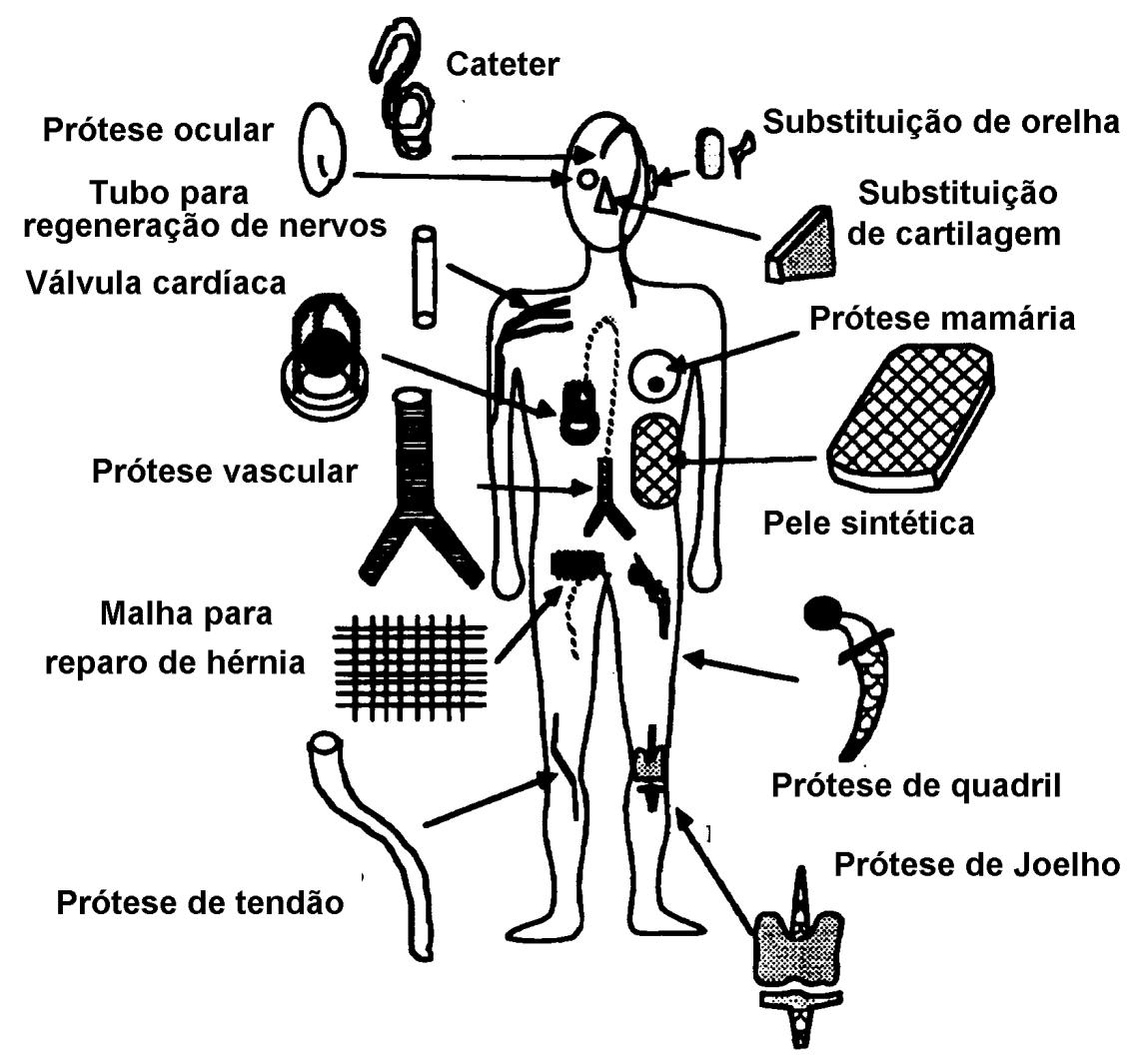

Figura 1. Esquema representativo de funções biológicas que podem ser substituídas por biomateriais (6).

Seu progresso se deveu, em grande parte, à evolução das ciências dos materiais, mas principalmente em função dos conhecimentos das interações biomateriais:células, dentro do conceito que "Biomateriais modernos não devem apenas preencher espaço, mas sim, devem estar associados a uma resposta biológica específica, disparada por sinais que incluem: correntes elétricas, distribuição eletrônica, conformação molecular, estado de agregação ou propriedades físico-químicas locais particulares, características estas que podem ser introduzidas por arranjos especiais de grupos funcionais sobre uma estrutura polimérica, reações de reticulação, propriedades particulares de superfícies e arranjos macromoleculares" $(7,8)$.

Para o desenvolvimento de novos tecidos artificiais três estratégias normalmente são adotadas (2):

a - Utilização de células isoladas do próprio paciente ou células substitutas. Esta aproximação evita as complicações cirúrgicas, porém, suas principais limitações 
incluem a capacidade das células manterem sua função dentro do recipiente em que são estocadas e também a rejeição imunológica.

b - Utilização de substâncias que induzem a regeneração do tecido danificado. São exemplos os fatores de crescimento, fatores de adesão, biomateriais que induzem a formação de novos tecidos.

c - Utilização de células colocadas dentro ou em matrizes poliméricas. Este tipo de material pode ser utilizado de duas maneiras:

1 - Como sistemas fechados, onde as células são isoladas do corpo por uma membrana que permite a permeação dos nutrientes. Estes sistemas podem ser implantados e usados como dispositivos extracorpóreos;

2 - Como sistemas abertos, onde as células aderidas à matriz polimérica são implantadas e tornam-se incorporadas ao tecido.

Dentre as considerações acima, uma das direções no desenvolvimento de biomateriais para área de engenharia de tecido é a criação de matrizes extracelulares sintéticas $(3,9,10)$, para atuarem como sítios de ancoragem e servirem como um suporte tridimensional para crescimento do novo tecido. Pode-se dizer que as MECs utilizadas em engenharia de tecido exercem três papéis importantes: Primeiro, as MECs facilitam a localização e a liberação de células para sítios específicos do corpo, em segundo lugar, elas definem e mantém um espaço tridimensional para a formação de novos tecidos com estrutura apropriada, e por último, elas guiam o desenvolvimento de novos tecidos (3).

Portanto, as MECs, de origem sintética ou derivadas de polímeros naturais, devem apresentar as seguintes características:

a - biocompatibilidade e a capacidade de sustentar o crescimento celular;

b - propriedades mecânicas condizentes em relação ao tecido a ser reconstruído;

c - velocidade de degradação compatível com aquela de crescimento do tecido para o qual serve como suporte;

d - permitir a associação destas matrizes tridimensionais com fatores de crescimento celular específicos para indução de respostas celulares mais rápidas e mais específicas ou possuir intrinsecamente propriedades diretamente relacionadas com a 
remodelagem do tecido, como ocorre nos tecidos nervoso e ósseo, em relação a propriedades elétricas do material $(11,12)$.

Estas propriedades, entretanto, restringem significativamente o número de materiais que possam ser utilizados como MEC. Embora vários polímeros venham sendo propostos (15), os mais utilizados são os poliésteres do tipo ácido poliglicólico e polilático individualmente ou na forma de copolímeros (Figura 2) (14) e os de origem natural.

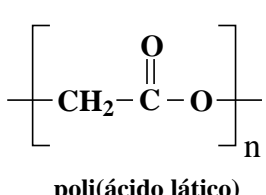

poli(ácido lático)

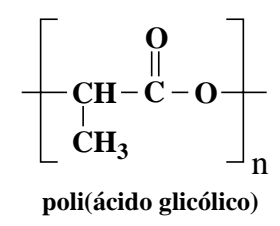

poli(ácido glicólico)

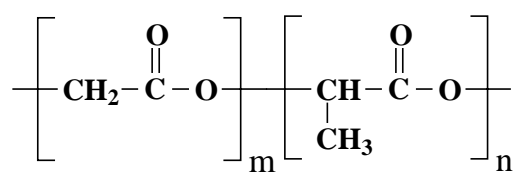

poli(ácido lático-co-glicólico)

Figura 2. Polímeros sintéticos normalmente utilizados para construção de MEC para a área de engenharia de tecido.

Os polímeros naturais, via de regra derivados de polímeros presentes na matriz extracelular, incluem as proteoglicanas (15), colágeno (16) e elastina (17). Além da elevada biocompatibilidade, sabe-se que por interação com receptores específicos na superfície celular, polímeros como o colágeno e as proteoglicanas participam de processos que regulam a expressão fenotípica da célula e, portanto, a manutenção não apenas da morfologia e função do tecido, mas também da sua remodelagem (18).

Nesta categoria enquadram-se ainda os materiais inteligentes (19), biomiméticos (20). Dentro destes novos conceitos, o colágeno é uma proteína potencialmente interessante para a confecção de biomateriais devido a algumas de suas propriedades naturais (21). Essas propriedades incluem: baixa resposta imunológica mesmo quando extraído de fonte heteróloga; baixo índice de alergenicidade (cerca de 2\% para colágeno heterólogo) que pode ser reduzido mais ainda pela remoção dos telopeptídeos $\mathbf{N}$ e $\mathbf{C}$ terminais, tornando-o altamente biocompatível; biodegradabilidade (susceptível à ação de colagenases); habilidade em promover crescimento celular; propriedades hemostáticas (ativação do processo de coagulação) e susceptível a modificações químicas. Em virtude dessas propriedades o colágeno possui uma posição privilegiada como biomaterial em diversas aplicações como, reconstrução de tecidos moles (21), revestimento de queimaduras e outras lesões (22), suporte para crescimento de nervos 
periféricos (23) e como agente hemostático (24). Além do que, pode ser utilizado sob diversas formas como, membranas, esponjas, géis, pó, filmes, tubos, etc (25).

O colágeno pode ser utilizado na sua forma nativa ou ser modificado quimicamente por esterificação (26), acilação (27) e desaminação dos grupos $\varepsilon$-amino da lisina ou proteção de grupos guanidino dos resíduos de arginina (28), para dar origem a materiais biocompatíveis e com propriedades físicas bastante diferenciadas daquelas do colágeno nativo (29). Os materiais resultantes são matrizes colagênicas carregadas positiva ou negativamente. Um processo interessante para a preparação de materiais de colágeno carregados negativamente a $\mathrm{pH}$ 7,4, é a hidrólise seletiva dos grupos carboxamidas dos resíduos de aminoácidos asparagina (Asn) e glutamina (Gln) presentes nas cadeias $\alpha$ do tropocolágeno (30).

Sendo assim, a utilização de MEC formadas por colágeno ou colágeno:elastina obtidas de tecidos heterólogos, dos quais células e outros componentes responsáveis por respostas biológicas não desejáveis tenham sido convenientemente removidos, vem sendo amplamente utilizadas (31,32). Exemplos de aplicação de MEC de colágeno e colágeno: elastina incluem a reprodução da estrutura da musculatura lisa funcional de parte de vesícula biliar (33) a reconstrução da derme em queimados, cirurgias bucomaxilofacial e cirurgias plásticas reconstrutivas com a finalidade de recompor perda extensa de tecido mole (34), como suporte para crescimento de fibras musculares lisas, células endoteliais, hepatócitos (35) e condrócitos (3) e também com materiais de recobrimento de tecidos sintéticos, como suporte para o crescimento da neoíntima e como conseqüência maior hemocompatibilidade de próteses vasculares de origem sintética (36).

Baseado nas informações mencionadas, materiais colagênicos são matéria prima em potencial não só para utilização como biomaterial convencional, mas também como suporte para crescimento de tecido, uma vez que pode ser facilmente obtido e utilizado tanto na forma nativa quanto na forma modificada.

Como mencionado anteriormente, na conceituação moderna, biomateriais não devem ter como função apenas o preenchimento de espaço (37), eles devem ser programados para estimular uma resposta biológica específica que depende de algumas propriedades particulares como: distribuição eletrônica, conformação molecular, estado de agregação ou propriedades físico-químicas específicas do biomaterial. Estas 
características podem ser introduzidas por arranjos especiais de grupos funcionais sobre uma estrutura polimérica, reações de reticulação, propriedades de superfície e arranjos macromoleculares (8). O desenvolvimento desses biomateriais são baseados nos mecanismos que controlam a função que se deseja substituir e na relação estrutura do material com a propriedade que se pretende obter.

Portanto, para o desenvolvimento destes materiais é necessário o conhecimento detalhado das propriedades físico-químicas e estruturais do material, que é realizado por técnicas específicas, do processo de obtenção, assim como o entendimento das interações da interface biomaterial:tecido.

Outras propriedades dos biomateriais modernos são:

a) Tensão superficial (38-40) é um parâmetro importante na interação de células com a superfície do material, uma vez que a tensão superficial está relacionada com a adsorção de proteínas que é o primeiro evento que ocorre quando se expõe um material ao sangue. A adsorção de proteínas pela superfície do material minimiza a tensão interfacial estabelecida entre o sangue e a superfície, ou seja, quando a energia livre interfacial sólido-líquido é alta, proteínas interagem fortemente com a superfície para diminuir esta diferença de energia que pode ser alcançada pela adsorção de uma ou mais camadas protéicas. Este evento irá ocorrer até a anulação da energia interfacial $(38,39)$. Caso a superfície implantada tenha baixa tensão interfacial, a força motriz para adsorção de proteínas é baixa, a constante de equilíbrio do processo de adsorção é pequena ocorrendo uma pequena adsorção. Nestas circunstâncias, as interações da proteína no estado adsorvido, são próximas da interação proteína:sangue, sofrendo desta maneira um mínimo de distorção, mantendo-se, na situação adsorvida, uma conformação similar àquela do seu estado nativo, resultando numa maior hemocompatibilidade.

b) Propriedades estruturais podem influenciar a adesão celular na superfície dos materiais. SCHOR e colaboradores (41), por exemplo, trabalhando com colágeno possuindo diferentes estruturas (colágeno nativo, colágeno nativo fibrilado e colágeno desnaturado), observaram que enquanto a adesão celular na superfície de colágeno desnaturado era dependente da presença de soro fetal, a adesão na superfície do colágeno nativo não era significativamente afetada pela presença ou ausência do soro. Observou-se também que as células aderidas ao colágeno nativo, eram rapidamente 
desprendidas pela ação da tripsina, enquanto para o colágeno nativo fibrilado as células aderidas eram relativamente insensíveis a ação da mesma.

c) Propriedades piro ou piezelétricas (12) são capazes de gerar estímulos que mimetizam os mecanismos básicos do reparo do tecido nervoso (42) e ósseo (43). Materiais com estas propriedades vem sendo estudados para utilização também na área cardiovascular, tem-se demonstrado que materiais dielétricos promovem um aumento na liberação de prostaciclina (proteína que atua na prevenção da coagulação) e uma diminuição na liberação de tromboxana $\mathrm{A}_{2}$ (proteína que atua na formação de trombos), diminuindo assim o índice de trombogenicidade (44).

d) Densidade de carga superficial pode influenciar a migração e adesão celular, assim como o tipo de tecido a ser formado. Shelton e Davies (45) estudando a reação de osteoblastos sobre superfícies carregadas assim como o processo de mineralização destas superfícies mostrou que a natureza da carga superficial influenciava o modo de adesão dos osteoblastos sobre a superfície do polímero, além disso, mostraram também que o processo de mineralização era diferente para polímeros carregados positiva ou negativamente. Enquanto a mineralização em polímeros carregados positivamente ocorria diretamente sobre a superfície do material, para polímeros carregados negativamente a mineralização ocorria a “distância” da superfície. Krukowski (46) e colaboradores trabalhando com polímeros carregados mostraram que superfícies carregadas positivamente induziam a formação de tecido conectivo, enquanto superfícies carregadas negativamente estimulavam a formação de tecido ósseo intramedular.

e) Biodegradabilidade controlada vem sendo utilizada na área de engenharia de tecido na construção de matrizes extracelulares sintéticas (MECs) para a substituição de tecidos moles (3). A biodegradabilidade é uma propriedade importante no desenvolvimento de MECs, estas devem ter velocidade de degradação compatível com aquela de crescimento do tecido, ou seja, a medida que ocorrer a formação do novo tecido, estas devem ser degradadas com mesma velocidade. Polímeros biodegradáveis vêm sendo utilizados também na área de liberação de fármacos (47).

Embora materiais com as propriedades descritas acima terem sido desenvolvidos, uma das grandes desvantagens da utilização de polímeros de origem sintética e mesmo de polímeros naturais como MEC, é o desencadeamento de respostas 
inflamatórias (48) e a ausência de sinais de reconhecimento celular (48), principalmente em matrizes sintéticas. Para o caso dos materiais propostos neste trabalho, MEC de colágeno aniônico:elastina, além da presença da seqüência RDG ser intrínseca à estrutura primária da matriz colagênica (18) e da alta biocompatibilidade que este materiais já demonstraram na forma de membrana, compósitos com hidroxiapatita e matrizes tridimensionais na reconstrução do tecido ósseo (49-53), em trabalho anterior e com os mesmo materiais implantados no subcutâneo de rato (54), os explantes de até 100 dias mostraram evidências de um comportamento atípico da reação inflamatória. Esta reação foi caracterizada pela baixa intensidade do processo crônico, com evidências de integração dos materiais estudados junto ao tecido conjuntivo (54). Esta redução na intensidade do processo inflamatório crônico associada à integração da MEC sugerem o alto potencial destas matrizes como materiais para a reconstrução de tecidos moles, sem a necessidade do cultivo celular "in vitro", técnica usualmente utilizada na engenharia de tecidos. 


\section{OBJETIVO}

Este trabalho teve como objetivo o estudo da integração ao tecido conjuntivo de matrizes tridimensionais acelulares de colágeno aniônico:elastina com densidade de carga negativa variável destinados à engenharia de tecidos. 


\section{EXPERIMENTAL}

Pericárdio bovino (PB): foi fornecido pela Braile Biomédica S.A. (São José do Rio Preto), já desengordurado e obtido de animais com idade entre 30 e 60 meses. O PB foi submetido a lavagem com solução salina ( $\mathrm{NaCl}$ 0,9\%) para remoção do sangue impregnado no material. Em seguida, lavou-se com água deionizada para remoção do excesso de solução salina. Após tais procedimentos, o PB foi colocado em álcool etílico $10 \%$ por 1 hora; este procedimento foi repetido aumentando-se gradualmente a concentração da solução etanólica (de 10 em 10\%) até atingir a concentração de 70\% para ser mantido em estoque.

III.1. Hidrólise Seletiva de Grupos Carboxamidas da matriz Colagênica: PB de dimensões de $10 \times 10 \mathrm{~cm}$ foram tratados a $20^{\circ} \mathrm{C}$ e por tempos de 24 e $48 \mathrm{~h}$, com uma solução alcalina contendo sulfatos e cloretos de $\mathrm{K}^{+}, \mathrm{Ca}^{+}$e $\mathrm{Na}^{+}$(56). Após a estabilização dos materiais com uma solução neutra também contendo cloretos e sulfatos dos cátions acima citados por um período de $6 \mathrm{~h}$, o excesso de sais residuais ainda presentes foram removidos por lavagens sucessivas com ácido bórico a 3\% (3x, 6h), EDTA 0,3\% a pH 11 (3x, 6h) e água destilada $(6 \mathrm{x}, 2 \mathrm{~h})$, seguido da estabilização do material em tampão fosfato $0,14 \mathrm{molL}^{-1}$ a pH 7,4 (TF) . Após este procedimento as peças de PB foram lavadas 3x15min com água destilada, congeladas em nitrogênio líquido e submetidas à liofilização em um equipamento da EDWADS modelo FREEZE DRYER Modulyo, até peso constantes e mantidas na geladeira na forma seca. Por este procedimento, aproximadamente 46 e 87 cargas negativas adicionais são introduzidas por tratamentos de 24 e 48h, respectivamente (56).

\section{III.2. Caracterização dos materiais}

III.2.1. Calorimetria Exploratória Diferencial: As amostras de PB foram analisadas por Calorimetria Exploratória Diferencial (DSC) em um equipamento DSC 2010 da TA Instruments calibrado previamente em termos de temperatura e fluxo de calor com o padrão de índio (In). As amostras de PB tratadas por 24 e 48h e de aproximadamente 15mg foram mantidas em tampão fosfato $\mathrm{pH}$ 7,4 até o momento das medidas, quando então foram colocadas em suportes de amostras não herméticas, de $6 \mathrm{~mm}$ de diâmetro por $2 \mathrm{~mm}$ de 
altura, apropriadas para estas medidas. Como referência, utilizou-se um suporte de amostra vazio. As medidas foram realizadas numa razão de aquecimento de $5^{\circ} \mathrm{C} / \mathrm{min}$ e em atmosfera dinâmica de nitrogênio, com fluxo de 60ml/min. O comportamento térmico destas amostras foi comparado com aquele do pericárdio bovino nativo.

III.2.2. Microscopia eletrônica de varredura (MEV): As amostras de PB acelularizadas, por se tratarem de tecido conjuntivo rico em fibras colágenas foram estudadas por esta técnica a fim de complementar as observações de DSC, principalmente para avaliar os níveis de alteração da estrutura microfibrilar da matriz colagênica.

Todas fotomicrografias para os materiais estudados foram obtidas em um equipamento ZEISS DSM 960, operando com feixe de elétrons entre 10 e $20 \mathrm{keV}$ com amostras recobertas com ouro em um metalizador Balsers modelo SDC 050. Comparações foram feitas também com o material de partida, o pericárdio bovino nativo.

III.2.3. Microscopia eletrônica de transmissão (MET): As análises de MET foram realizadas no Departamento de Patologia da Faculdade de Medicina de Ribeirão Preto (FMRP-USP). Todas as fotomicrografias foram obtidas em um equipamento ZEISS Mod. PQ 2300, operando com feixe de elétrons de $60 \mathrm{keV}$ e os materiais estudados foram aquelas descritas acima em comparação com o pericárdio nativo. Este estudo tem como objetivo observar eventuais alterações na sub-periodicidade (estriação transversal) e nos diâmetros (corte transversal) do sistema microfibrilar, complementado os estudos de DSC e MEV. O tratamento das amostras incluiu a passagem das mesmas pelas etapas de fixação, desidratação, infiltração e inclusão. Em seguida, o material foi submetido a ultramicrotomia, sendo feito cortes de $0,05 \mu \mathrm{m}$ de espessura, para posterior impregnação com metais pesados.

\section{III.3. Implantes em subcutâneo de rato}

Para proceder ao implante, o material foi cortado em amostras, de cerca de 1,0 cm que foram lavadas previamente com água destilada por 3x de 0,5h cada para remoção do tampão fosfato seguido de lavagens com soluções de etanol/água 15, 30, 50, 70, 95\% e 
solvente puro e acetona:etanol nas mesmas proporções. Esta lavagem com solventes orgânicos, feita por 30 minutos em cada passo, tem com objetivo a desidratação gradual e total das amostras, sem perdas significativas de estrutura da matriz colagênica.

Outro procedimento utilizado foi o congelamento das amostras em nitrogênio líquido seguido de liofilização em um equipamento EDWARDS modelo FREEZE DRYER Modulyo, até peso constante. Este processo de liofilização foi utilizado porque a rotina para a preparação dos materiais de implante inclui tal técnica.

O procedimento geral consistiu de implantes de colágeno aniônico:elastina tratados em meio alcalino por períodos de 24 e 48 horas, aproximadamente $1 \mathrm{~cm}^{2}$, com tricotomia prévia da região dorsal escapular e pélvica (lado direito, incisões de $2 \mathrm{~cm}$ ), em ratos WISTAR machos (figura 4), com um peso médio de 220 g, divididos em 3 grupos: PB24 (pericárdio hidrolisado por 24 horas), PB24 + ATB (pericárdio hidrolisado por 24 horas e com antibiótico incorporado - gentamicina) (57) e PB48 (pericárdio hidrolisado por 48 horas); foram implantadas 6 amostras por período. (TABELA 1).

A via azida foi o método escolhido para incorporar a gentamicina covalentemente, pois não deixa resíduos tóxicos no material. Essa etapa de incorporação da gentamicina foi realizada como objetivo de estudo de outro pesquisador do grupo (57), sendo implantado para avaliação em conjunto com o material utilizado neste trabalho.

TABELA 1. Esquema para a rotina para a avaliação integração em subcutâneo de rato de matrizes tridimensionais de colágeno aniônico:elastina com densidade de carga negativa variável.

\section{Número de Implantes/Grupo}

\begin{tabular}{c|c|c|c|c}
\hline Período (dias) & PB24 & PB24 + ATB & PB48 & $\mathbf{n}^{\circ}$ de animais \\
\hline 14 & 6 & 6 & 6 & 6 \\
\hline 60 & 6 & 6 & 6 & 6 \\
\hline 120 & 6 & 6 & 6 & 6 \\
\hline 180 & 6 & 6 & 6 & 6 \\
\hline
\end{tabular}


Ao longo do experimento, os animais foram alimentados com uma dieta sólida e água ad libidum. Anestesia foi feita por meio de éter etílico e cada animal recebeu um total de 3 implantes, seguido de desinfecção com álcool iodado. Após tempos de 14, 60, 120 e 180 dias os animais, após anestesia com éter etílico, tiveram as áreas dos implantes removidas e fixadas em formaldeído por 48 horas seguido de rotina laboratorial para inclusão em parafina, e cortes subseqüente de $5 \mu \mathrm{m}$ de espessura.Os animais foram sacrificados com aumento da dosagem anestésica após a retirada dos materiais. Os procedimentos cirúrgicos foram realizados no centro de cirurgia experimental da Faculdade de Medicina de São José do Rio Preto (FAMERP).

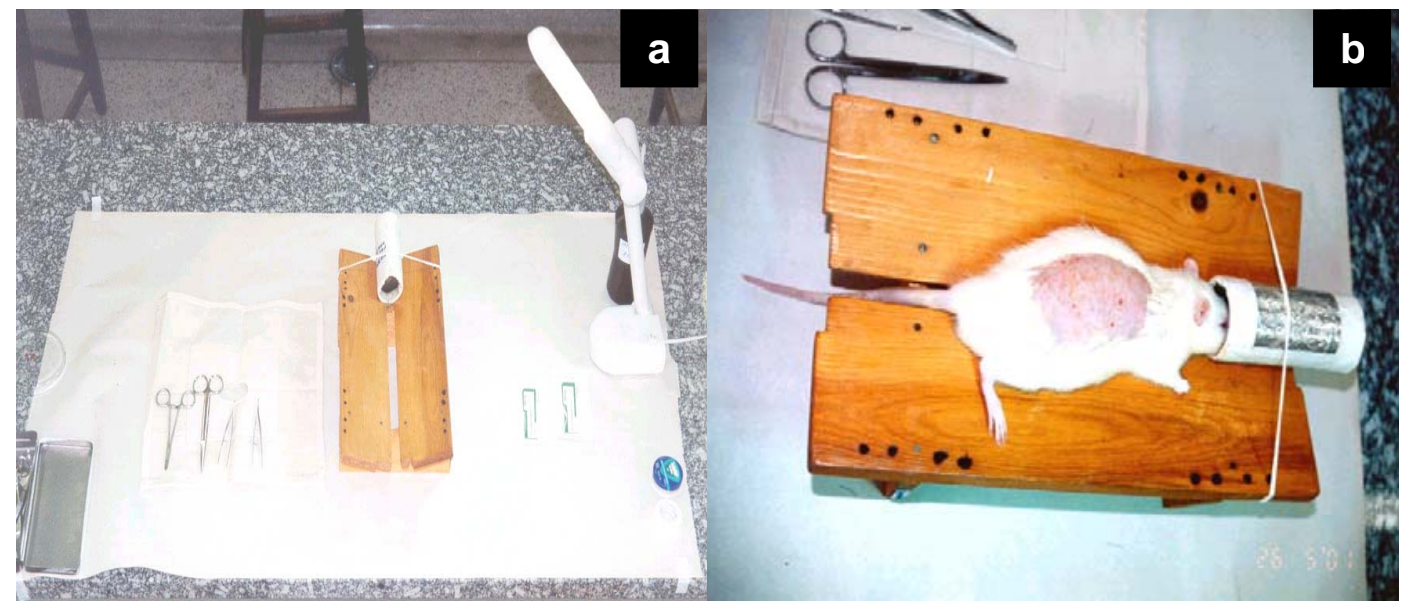

Figura 3. Fotografias mostrando: a.instrumental cirúrgico utilizado para o procedimento; b. rato sob anestesia e preparado para implantes após realização de tricotomia dorsal. 


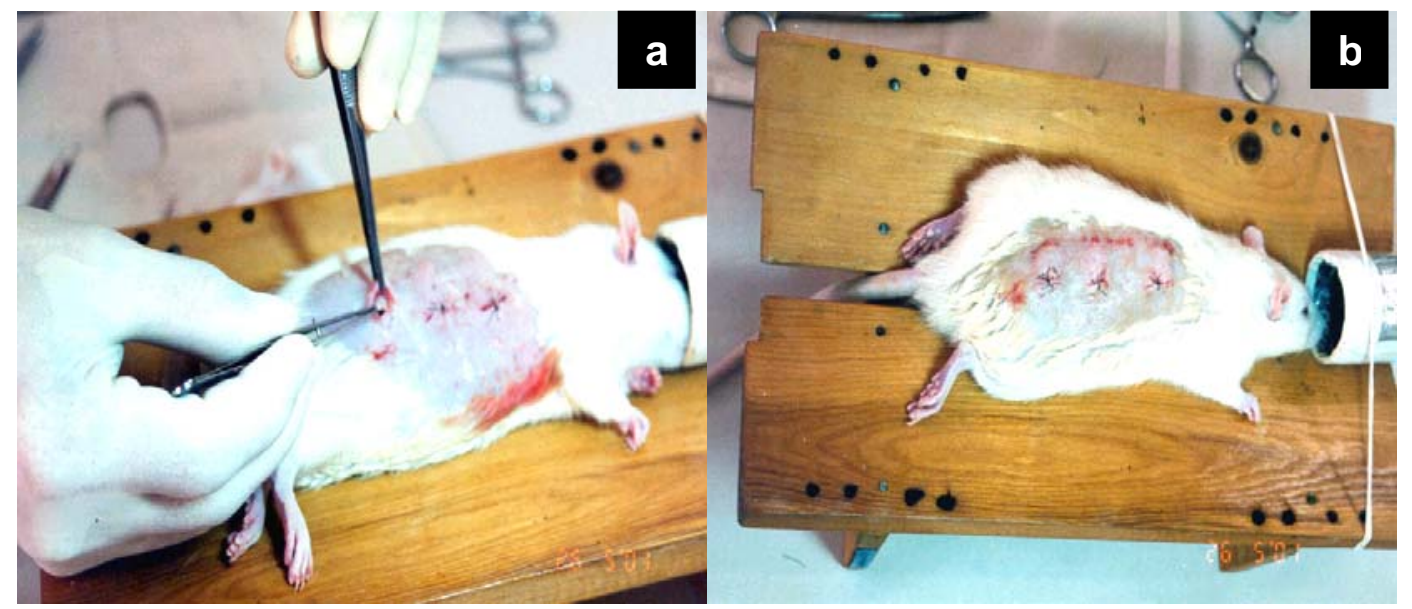

Figura 4. Fotografias mostrando: a. aplicação do material em região dorsal do rato; b. animal após término de procedimento cirúrgico.

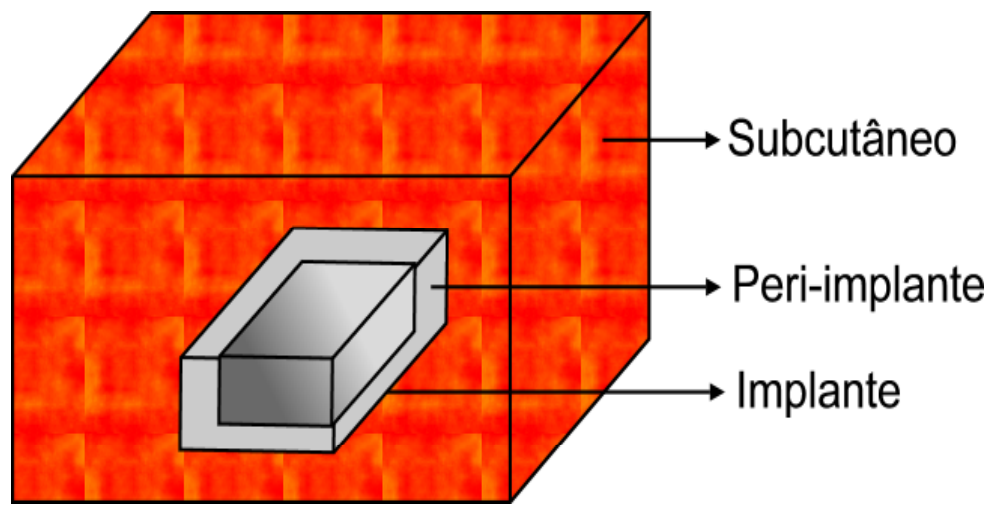

Figura 5. Esquema mostrando a localização do implante no subcutâneo do rato.

III.3.1. Microscopia de luz: O material foi fixado por 24 horas em paraformaldeído tamponado (4\%) e em seguida desidratado em álcool e incluído em paraplast. Cortes histológicos foram corados com hematoxilina-eosina (H.E.), tricrômico de Masson (TM) e Verhoeff. Estas técnicas têm como objetivos verificar histologicamente, por meio de colorações específicas, a quantidade, integridade, distribuição e a organização de fibras colágenas, elásticas e células após o tratamento alcalino. A H.E. apresenta os núcleos celulares em azul e citoplasma, fibras colágenas e elásticas em vermelho. O T.M. evidencia os núcleos em negro e citoplasma, vasos sangüíneos em vermelho brilhante, e colágeno em azul ou verde. O Verhoeff mostra as fibras elásticas em negro. As amostras foram 
processadas, passando pelas etapas de desidratação e embebição. Na etapa seguinte, as amostras foram incluídas em parafina. Após solidificação dos blocos, fez-se cortes seriados de $5 \mu \mathrm{m}$ de espessura, sendo montadas lâminas com cinco cortes/ lâmina. Após a desparafinização com xilol e hidratação, os cortes foram submetidos às colorações já citadas anteriormente. 


\section{RESULTADOS}

\section{IV.1. Avaliação da estrutura por estabilidade térmica}

A integridade da estrutura do colágeno é dependente, dentre outras variáveis, do pH que afeta diretamente a organização e a estrutura da molécula de tropocolágeno, uma tripla hélice formada por três cadeias polipeptídicas, no caso do colágeno do tipo 2 , duas alfa 1 e uma alfa 2. Outro parâmetro que afeta a estrutura destas matrizes são alterações introduzidas nas cadeias laterais dos aminoácidos, uma delas a hidrólise de grupos carboxamidas de resíduos de Asn e Gln, resultando em grupos carboxílicos. Uma determinação que estuda indiretamente esta organização são as medidas de estabilidade térmica avaliadas por calorimetria exploratória diferencial. A transição é denominada de temperatura de desnaturaçãoTd.

Os materiais descritos e utilizados neste trabalho foram motivo de trabalho anterior (54) e correspondem ao pericárdio nativo, aquele hidrolisado por 24 e 48 horas, cujas curvas de estabilidade térmica são mostradas, respectivamente pela figura 5. Enquanto para PB nativo (figura 6.a) e PB 24 (figura 6.b), apenas uma transição foi observada entre 67,2 e $57,0{ }^{\circ} \mathrm{C}$, uma indicação que o material apresenta características mais homogêneas, o PB 48 mostrou duas transições em 52,8 e 45,4 ${ }^{\circ} \mathrm{C}$ (figura 6.c), sugerindo um material mais heterogêneo. De qualquer forma, a presença destas transições indica que os materiais estudados preservam, pelo menos, a integridade de tropocolágeno, pois, no intervalo de temperatura estudado, o colágeno desnaturado não apresenta qualquer transição. Como avaliação geral, materiais de colágeno com grupos carboxílicos aumentados, como resultado da hidrólise de grupos carboxamidas de resíduos de Asn e Gln, diminuem sua estabilidade térmica quando equilibrados em $\mathrm{pH}$ 7,4 . 

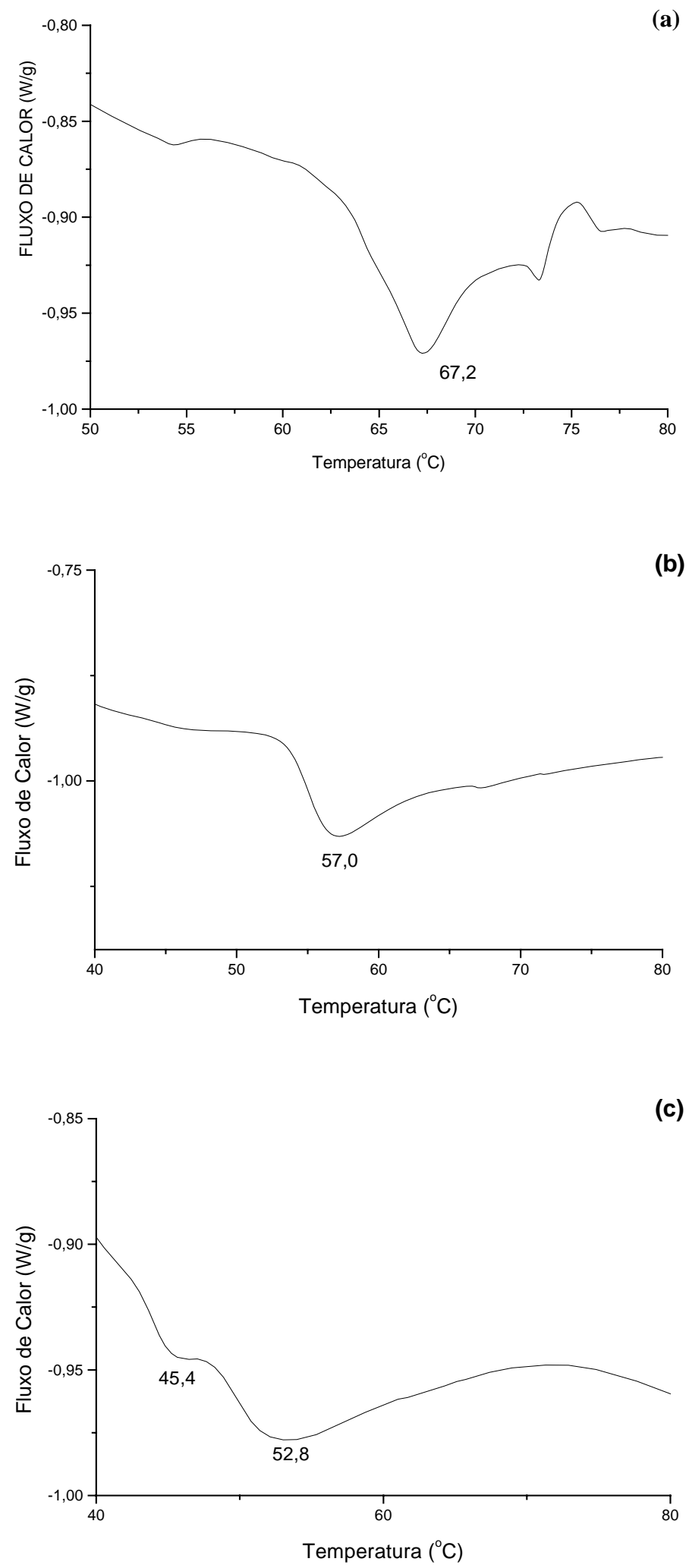

Figura 6. Temperatura de desnaturação (Td) para matrizes de colágeno: a - pericárdio nativo; b - pericárdio bovino com grupos carboxílicos adicionais resultantes da a hidrólise de grupos carboxamidas de resíduos de Asn e Gln após um tempo de hidrólise de 24 horas; c - idem por um período de 48 horas. 


\section{IV.2. Microscopia eletrônica de Varredura (MEV)}

Embora a técnica de DSC permita avaliar, relativamente, a estrutura da matriz colagênica, principalmente em relação à integridade do tropocolágeno, ela não permite avaliar a sua organização; esta se apresenta nos tecidos nativos como arranjo microfibrilar, podendo ser observada por microscopia eletrônica de varredura (figuras 7 e 8).

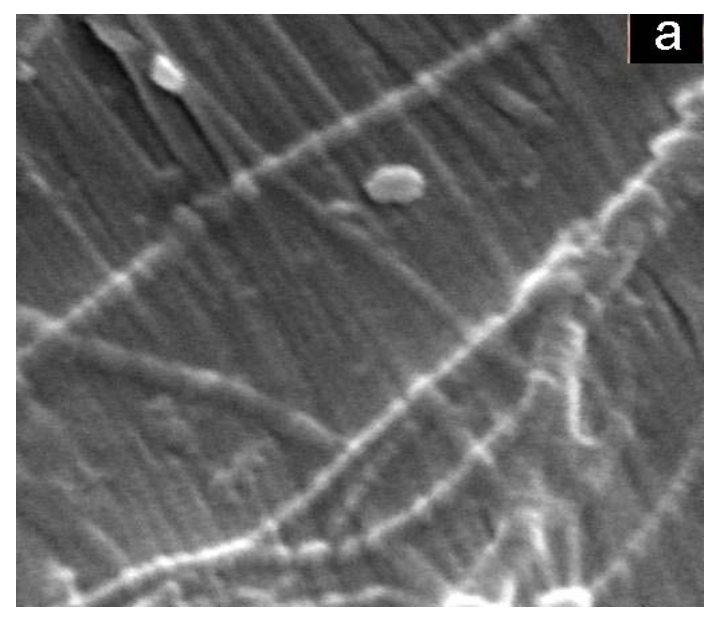

Figura 7. Micrografia de microscopia eletrônica de varredura para pericárdio bovino nativo equilibrado em pH 7,4 (30000x).
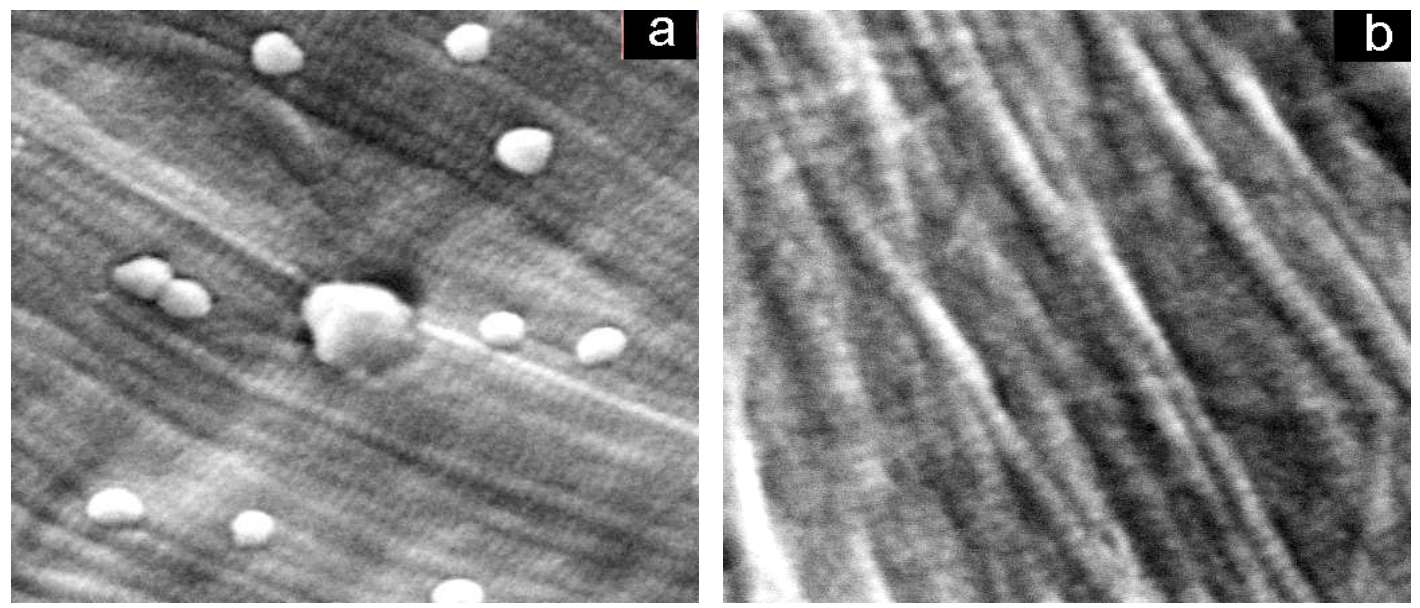

Figura 8. Micrografias de microscopia eletrônica de varredura para matrizes de pericárdio bovino equilibradas em pH 7,4: a - PB 24 horas (30000x);b - PB 48 horas (40000x). Formações esféricas observadas para o material de 24 horas, provavelmente, correspondem a resíduo de fosfato de sódio. 


\section{IV.3. Microscopia eletrônica de Transmissão (MET)}

Estes resultados foram confirmados por microscopia eletrônica de transmissão para os mesmos materiais (figura 9). À medida que se aumenta o número de grupos carboxílicos, além de uma fragmentação da microfibrila observada para o material hidrolisado por 24 horas, há também início de desagregação da estrutura microfibrilar do material hidrolisado por 48 horas, embora ainda sejam observadas as características da periodicidade do colágeno.
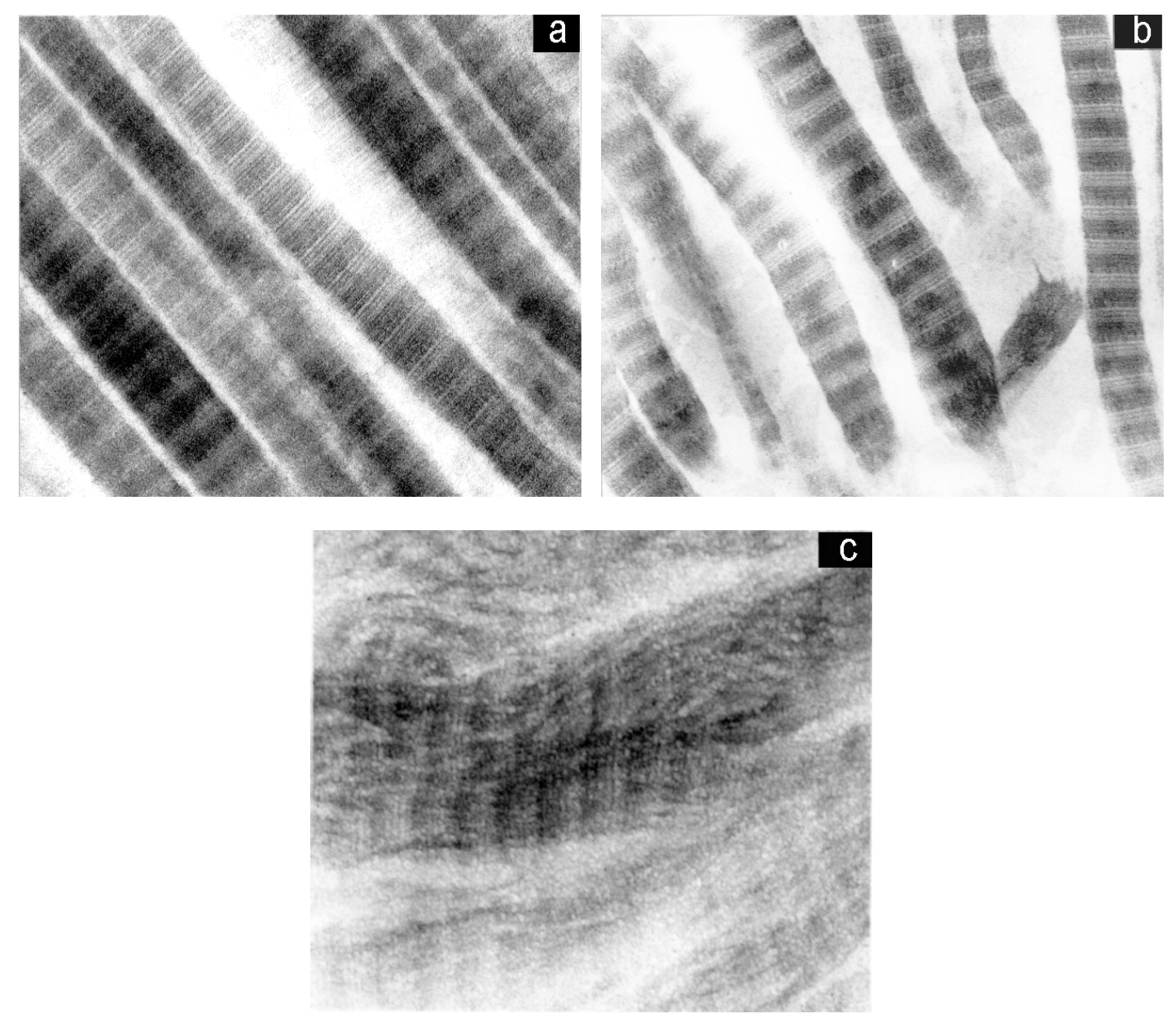

Figura 9. Micrografias de microscopia eletrônica de transmissão para matrizes de pericárdio bovino equilibradas em $\mathrm{pH}$ 7,4: a - PB nativo; b - PB 24; c - PB 48 horas (140.000x). 


\section{IV.4. Histologia dos Explantes}

Foram analisadas as amostras de PB tratado quimicamente em meio alcalino por períodos de 24 e 48 horas e denominados de PB24 e PB48, respectivamente. Visando o emprego desse material tanto em tecido subcutâneo quanto em tecido ósseo, foram implantadas amostras de PB24 incorporadas com antibiótico (gentamicina), denominado PB24 + ATB, para observar seu comportamento frente ao processo inflamatório. Tal processo foi feito utilizando o método via azida, pois este apresenta citocompatibilidade superior (58), à medida que não deixa resíduos tóxicos. Um exemplo de seu uso em tecido ósseo seria no tratamento de osteomielite (57). Os materiais foram implantados em subcutâneo de rato com explantes realizados após os tempos de 14, 60, 120 e 180 dias. Os resultados observados na microscopia de luz de cada explante examinado são descritos a seguir e as alterações evidenciadas foram graduadas de 0 (ausência de alteração) a 5+/5 (grau máximo de alteração).

\section{IV.4.1. Explantes após 14 dias}

O grau de fibrose peri-implante observado nos materiais estudados mostrou-se mais acentuado em PB24 (4+/5) (figura 10.a). Em PB24 + ATB (3+/5) (figura 10.b) e PB48 (2+/5), houve decréscimo de intensidade de tal processo.

Em todos os casos, o processo de neoformação vascular peri-implante apresentou-se com intensidade semelhante, variando de 2+/5 a 3+/5.

Quanto ao processo inflamatório, este apresentou predomínio de linfócitos, mostrando-se mais acentuado na região extra-pericárdica com discreta variação entre todos os explantes $(2+/ 5$ a 3+/5) (figuras 11.a, 11.b). Houve discreta quantidade de linfócitos na superfície dos explantes (1+/5 a 2+/5), não sendo observadas no interior do material implantado. 

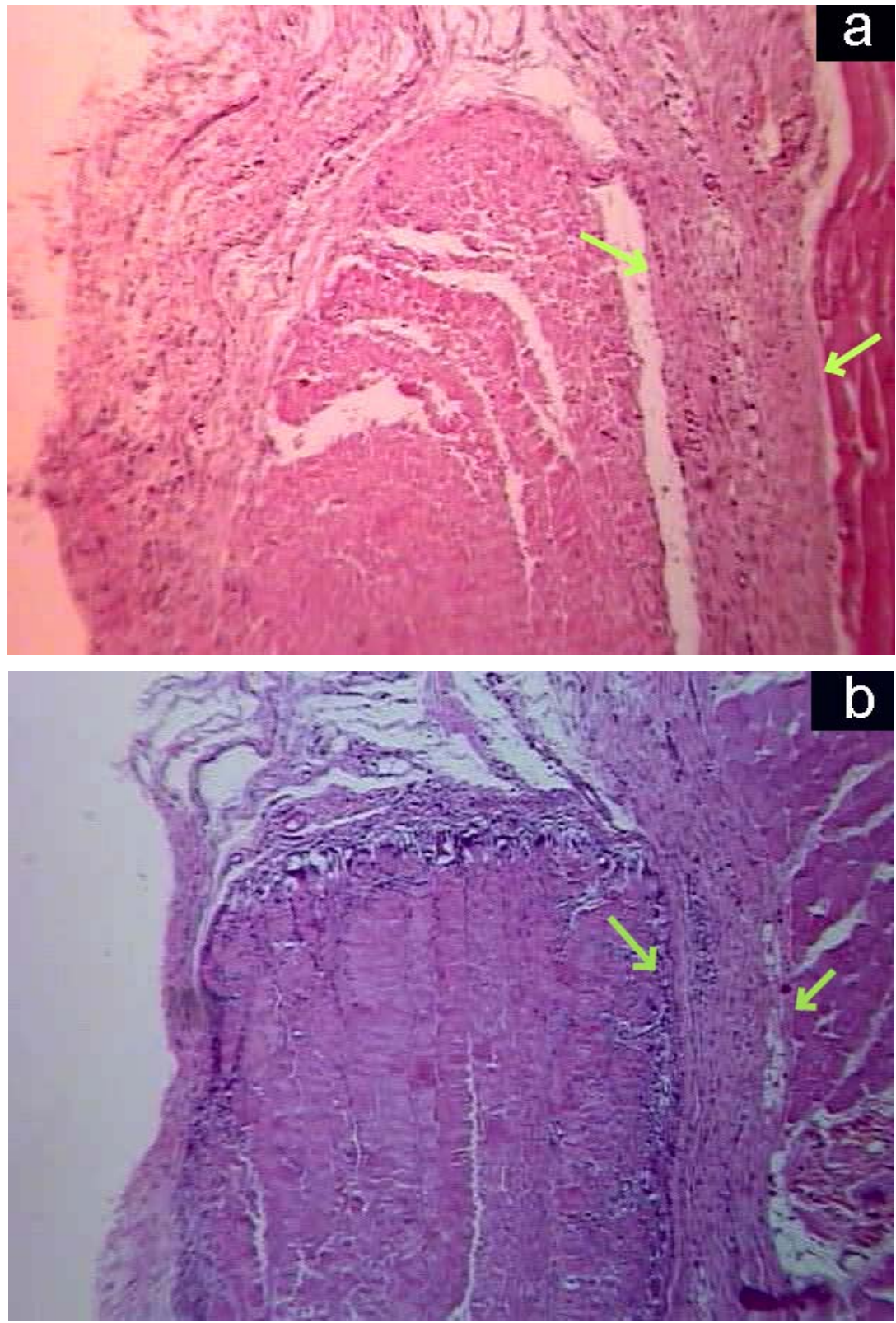

Figura 10. Micrografias após 14 dias de implante: a - (PB24) fibrose (setas verdes) peri-explante (5x) H.E; b. - (PB24 + ATB) fibrose entre as setas verdes (5x).H.E. 

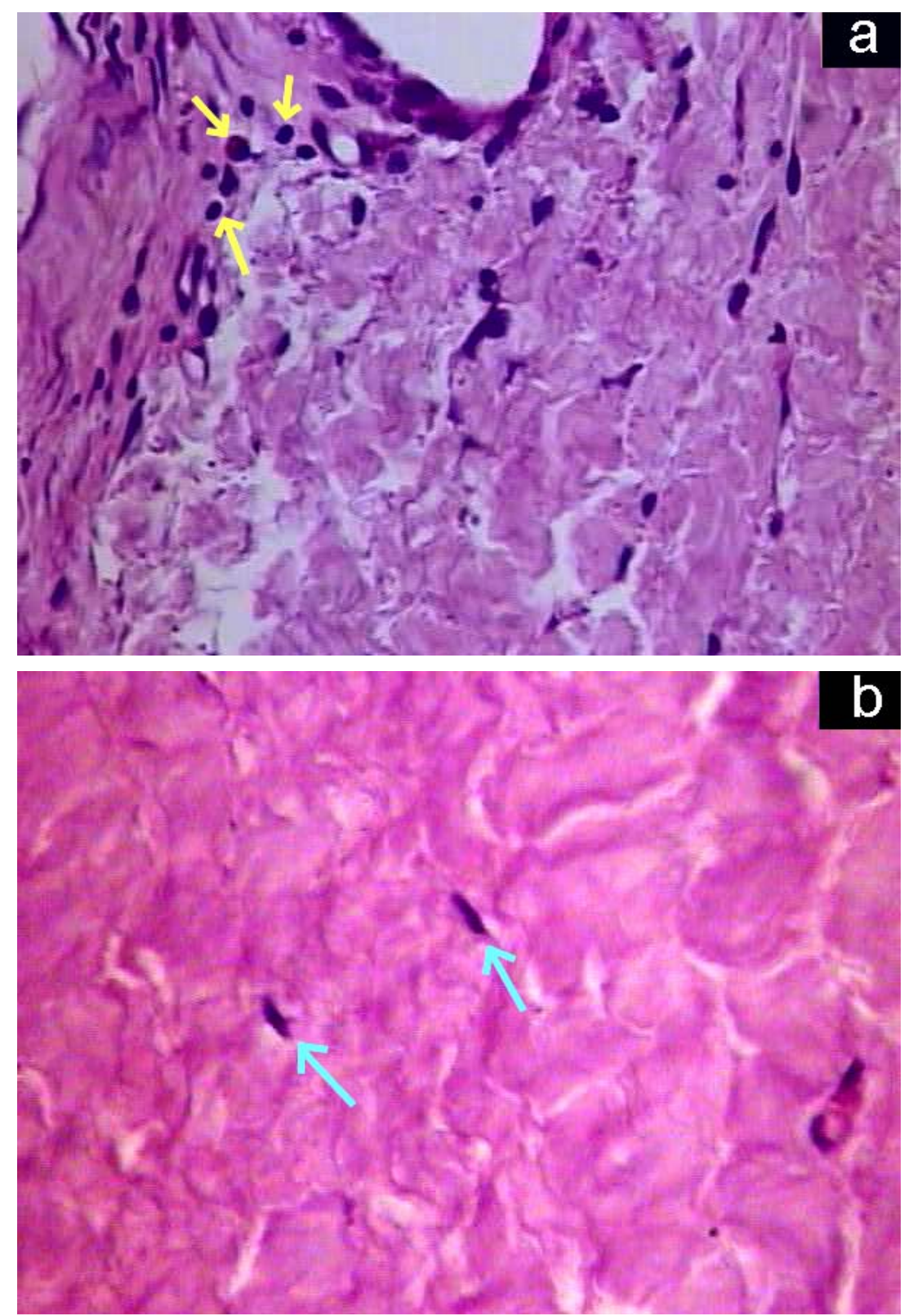

Figura 11. Micrografias após 14 dias de implante: a - (PB24 + ATB) infiltrado inflamatório discreto na superfície do explante (setas amarelas) (10x) H.E.; b - (PB48) ausência de células inflamatórias no interior do material (40x) H.E.; células fibroblastos “like”(setas azuis).

As fibras de colágeno mostraram-se mais preservadas nos explantes de PB24 $(1+/ 5)$ (figura 12.a), com a presença de fendas entre as mesmas em PB24+ATB (2+/5 a $3+/ 5)$ e presença de áreas de alterações degenerativas do colágeno em PB48 (3+/5) (figura 12.b). 

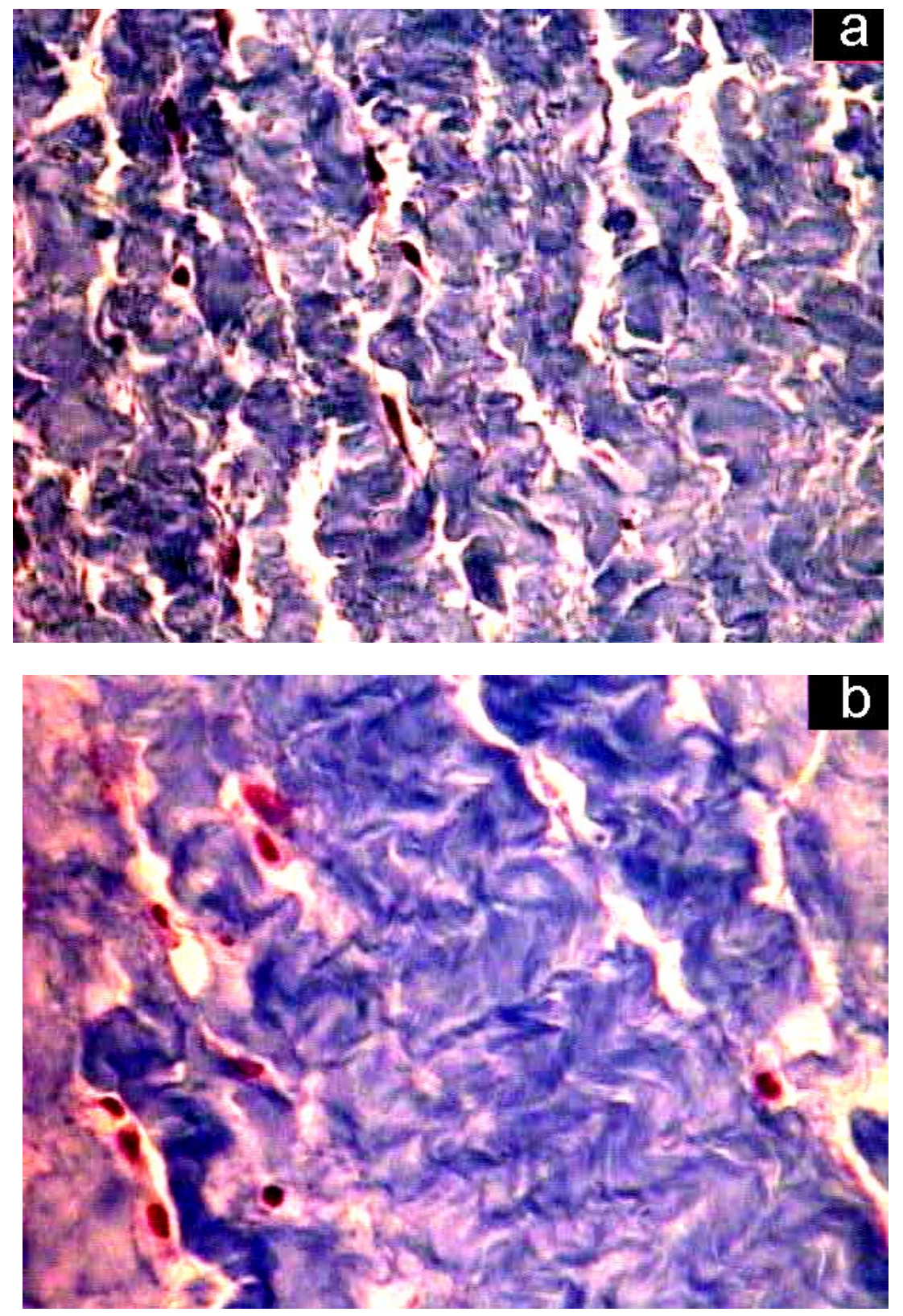

Figura 12. Micrografias de pericárdio bovino após 14 dias de implante: a - (PB24) preservação de 1+/5 das fibras colágenas (40x); b - (PB48) alterações degenerativas das fibras colágenas de 3+/5 (40x); Tricrômico de Masson.

A celularidade pós-implante dos materiais, comparada ao pericárdio nativo, mostrou-se discretamente aumentada no PB24 (3+/5) (figura 13.a) e normal em relação ao PB24+ATB (figura 13.b) e PB48 (2+/5), observando-se a presença de células fibroblastos "like” nos explantes. 

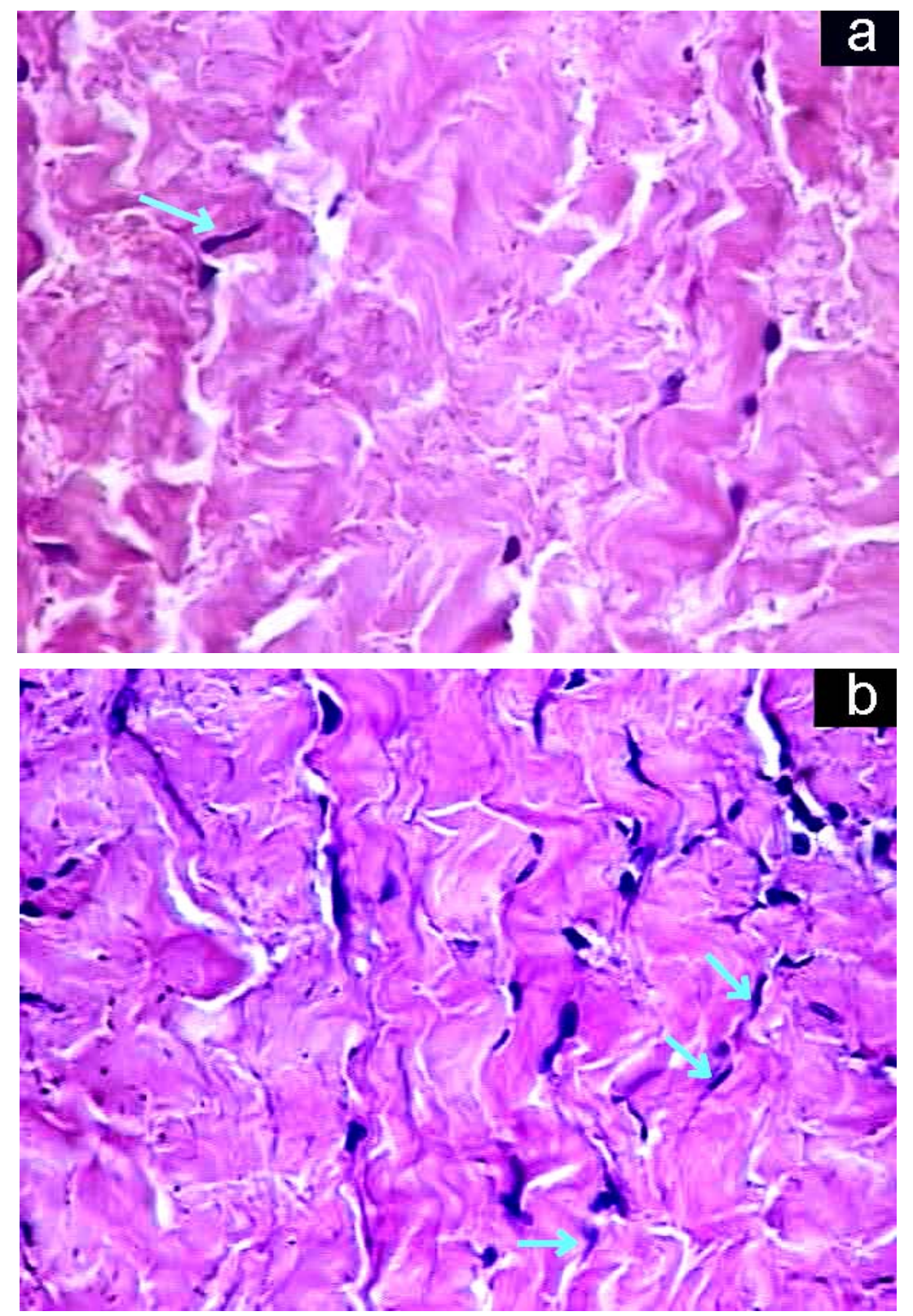

Figura 13. Micrografias após 14 dias: a - (PB24) celularidade no interior do material (40x) H.E.; b - (PB24 + ATB) celularidade do implante de 2+/5, (40x) H.E.; células fibroblastos "like” (setas azuis). 
TABELA 2. Quadro geral da resposta celular de explantes de pericárdio bovino submetido à hidrólise alcalina por períodos de 24 e 48 horas.

\begin{tabular}{|c|c|c|c|c|c|c|c|c|c|c|c|c|}
\hline \multirow[b]{2}{*}{ Dia de explante } & \multicolumn{4}{|c|}{ PB24 ${ }^{4}$} & \multicolumn{4}{|c|}{$\mathrm{PB}_{24}+\mathrm{ATB}^{4}$} & \multicolumn{4}{|c|}{ PB48 $^{4}$} \\
\hline & 14 & 60 & 120 & 180 & 14 & 60 & 120 & 180 & 14 & 60 & 120 & 180 \\
\hline $\begin{array}{l}\text { Fibrose peri- } \\
\text { implante } \\
\qquad \mathrm{N}^{1}=0+/ 5\end{array}$ & $4+/ 5$ & $4+/ 5$ & $3+/ 5$ & $3+/ 5$ & $3+/ 5$ & $2+/ 5$ & $3+/ 5$ & $3+/ 5$ & $2+/ 5$ & $3+/ 5$ & $3+/ 5$ & $4+/ 5$ \\
\hline $\begin{array}{l}\text { Neoformação } \\
\text { vascular peri- } \\
\text { implante }\end{array}$ & $2-3+/ 5$ & $2+/ 5$ & $3+/ 5$ & $2-3+/ 5$ & $2-3+/ 5$ & $2+/ 5$ & $3+/ 5$ & $3+/ 5$ & $2+/ 5$ & $2+/ 5$ & $3+/ 5$ & $2+/ 5$ \\
\hline
\end{tabular}

\begin{tabular}{l|c|c|c|c|c|c|c|c|c|c|c|c}
\hline Infiltrado inflamatório $\boldsymbol{N}=\mathbf{0 + / 5}$ \\
\hline superficial & $2+/ 5$ & $1+/ 5$ & $1+/ 5$ & - & $2+/ 5$ & $1+/ 5$ & $1+/ 5$ & - & $1+/ 5$ & $1+/ 5$ & - & - \\
\hline profundo & - & - & - & - & - & $1+/ 5$ & $1+/ 5$ & - & - & $1+/ 5$ & - & - \\
\hline peri-implante $^{2}$ & $2+/ 5$ & $2+/ 5$ & $1+/ 5$ & $1+/ 5$ & $3+/ 5$ & $1+/ 5$ & $2+/ 5$ & $1+/ 5$ & $3+/ 5$ & $3+/ 5$ & $0-1+/ 5$ & - \\
\hline
\end{tabular}

\begin{tabular}{|c|c|c|c|c|c|c|c|c|c|c|c|c|}
\hline \multicolumn{13}{|c|}{ Material implantado } \\
\hline $\begin{array}{l}\text { alterações em } \\
\text { fibras colágenas } \\
\mathrm{N}=0+/ 5\end{array}$ & $1+/ 5$ & $3+/ 5$ & $1+/ 5$ & $1+/ 5$ & $2-3+/ 5$ & $2+/ 5$ & $3+/ 5$ & $1+/ 5$ & $3+/ 5$ & $2-5+/ 5$ & $2+/ 5$ & $1+/ 5$ \\
\hline celularidade $^{3}$ & $3+/ 5$ & $2+/ 5$ & $2+/ 5$ & $2+/ 5$ & $2+/ 5$ & $2+/ 5$ & $2+/ 5$ & $2+/ 5$ & $2+/ 5$ & $2+/ 5$ & $2+/ 5$ & $2+/ 5$ \\
\hline
\end{tabular}

$1-\mathrm{N}$ : valor normal presente no pericárdio nativo

2 - infiltrado inflamatório mononuclear na área de fibrose

3 - celularidade do material após 14, 60, 120 e 180 dias

4 - PB24, PB24 + ATB e PB48 correspondem a amostras de PB tratado quimicamente em meio alcalino por períodos de 24 e 48 horas.

\section{IV.4.2. Explantes após 60 dias}

A fibrose observada em PB24 mostrou-se de maior intensidade dentre os explantes deste tempo (4+/5) (figura 14.a), seguida por PB48 (3+/5) (figura 14.b) e PB24+ATB (2+/5). Observaram-se ainda em alguns explantes de PB24 e PB24+ATB áreas focais de dissociação das fibras colágenas (figura 13.a) por fibrose moderada, de permeio a células fibroblastos “like” e vasos sangüíneos neoformados.

O processo de neoformação vascular peri-implante mostrou discreta variação de intensidade entre os explantes $(2+/ 5$ a $3+/ 5)$.

O infiltrado inflamatório mononuclear, com predomínio linfocítico, presente na região extra-pericárdica apresentou-se mais intenso nos explantes de PB48 (3+/5) (figura 14.b), e menos acentuada em PB24 + ATB (1+/5). Na superfície dos explantes houve menor intensidade de infiltrado inflamatório em PB48 (1+/5), sendo este discretamente maior em PB24 e PB24+ATB (2+/5). Na porção profunda do pericárdio, 
notou-se discreta quantidade de células inflamatórias mononucleares do tipo linfocítica em PB24+ATB e PB48.
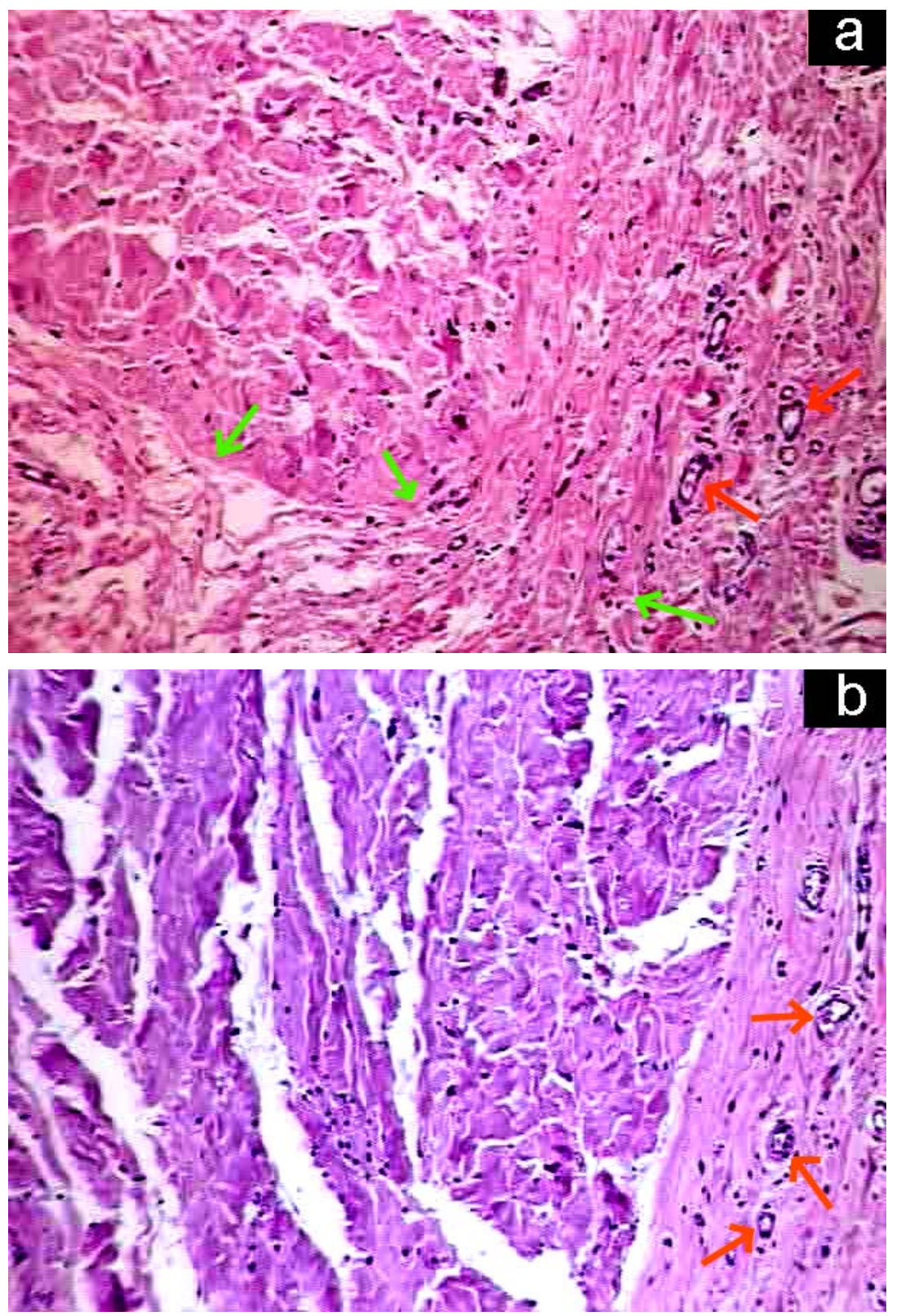

Figura 14. Micrografias de explantes após 60 dias: a - (PB24) dissociação das fibras colágenas do implante por fibrose (setas verdes) e vasos sangüíneos (setas vermelhas) (10x). H.E.; b - (PB48) fibrose (à direita) e infiltrado inflamatório na região superficial e média do material (10x) H.E.

As fibras colágenas mostraram alterações degenerativas que variaram de intensidade entre $2+/ 5$ a 3+/5 em todos os tempos de tratamento (figuras 15.a e 15.b). 

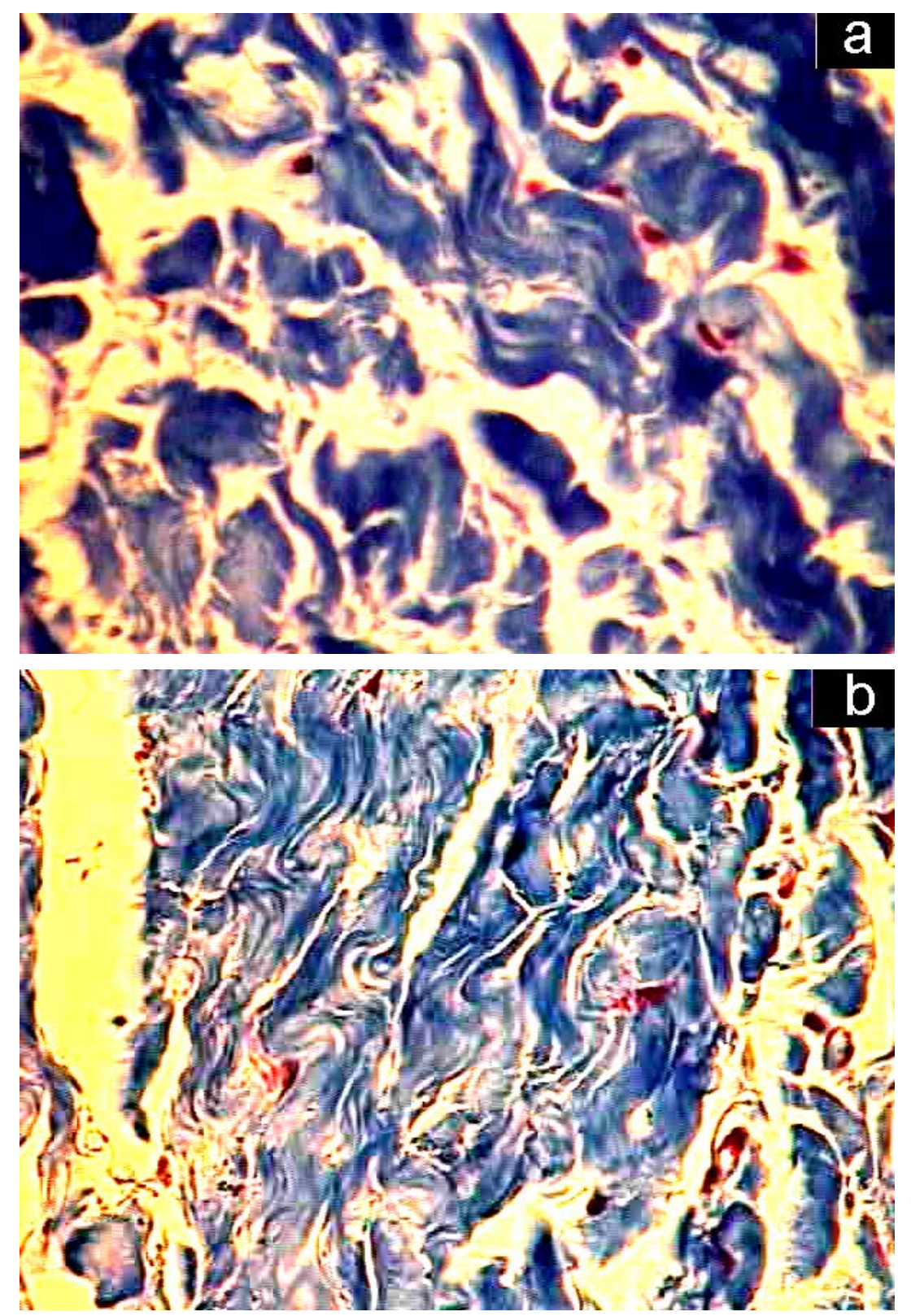

Figura 15. Micrografias de materiais corados com Tricrômico de Masson, após 60 dias: a - (PB24) fibras colágenas alteradas em 2+/5 (40x); b - (PB48) fibras colágenas alteradas em 3+/5 (40x).

Quanto à celularidade pós-implante, PB24, PB24 +ATB e PB48 foram similares em relação à presença de células fibroblastos "like” (células que, à microscopia de luz, são morfologicamente idênticas a fibroblasto; para comprovação celular, faz-se necessário uso de imunohistoquímica, método não empregado neste trabalho).

\section{IV.4.3. Explantes após 120 dias}

A fibrose peri-implante mostrou-se semelhante na maioria dos explantes $(3+/ 5)$ (figuras 16.a e 16.b), sendo mais acentuado em PB24 + ATB (4+/5). Observou-se áreas em que as fibras colagênicas dos explantes foram dissociadas pela fibrose peri-implante. 

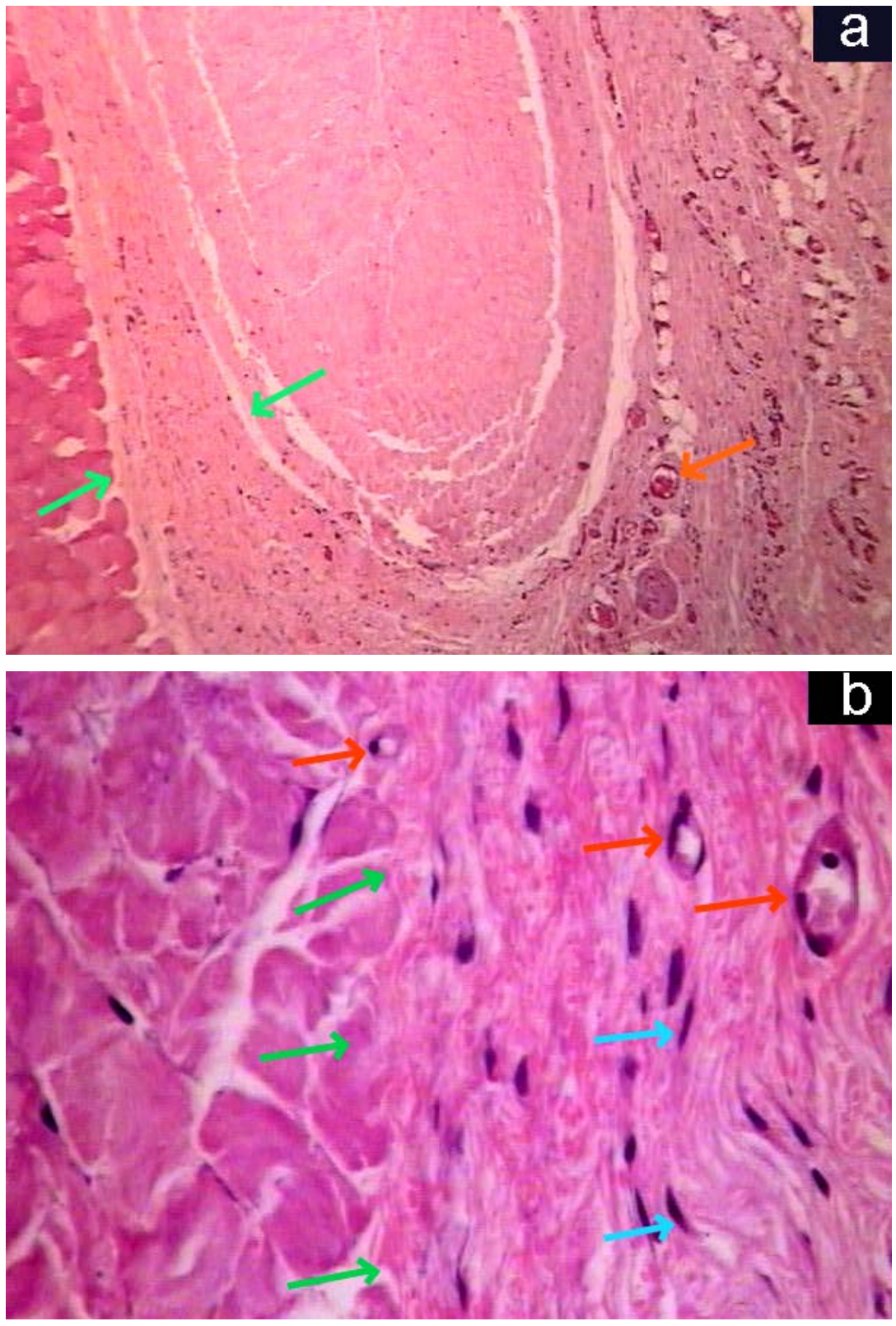

Figura 16. Micrografias após 120 dias de implante: a - (PB24) fibrose (setas verdes) ao redor do explante (5x), H.E.; b - (PB48) fibrose peri-explante (40x), H.E.. Presença de vasos sangüíneos (setas vermelhas).

A neoformação vascular peri-implante apresentou-se mais acentuada nos explantes de PB24 e PB24 +ATB (3+/5). Em vários explantes, os vasos neoformados acompanhavam a fibrose peri-implante que penetrava entre as fibras colagênicas dos explantes. De modo geral, observou-se que a vascularização estava presente nas porções superficial e profunda dos materiais estudados (figura 17). 

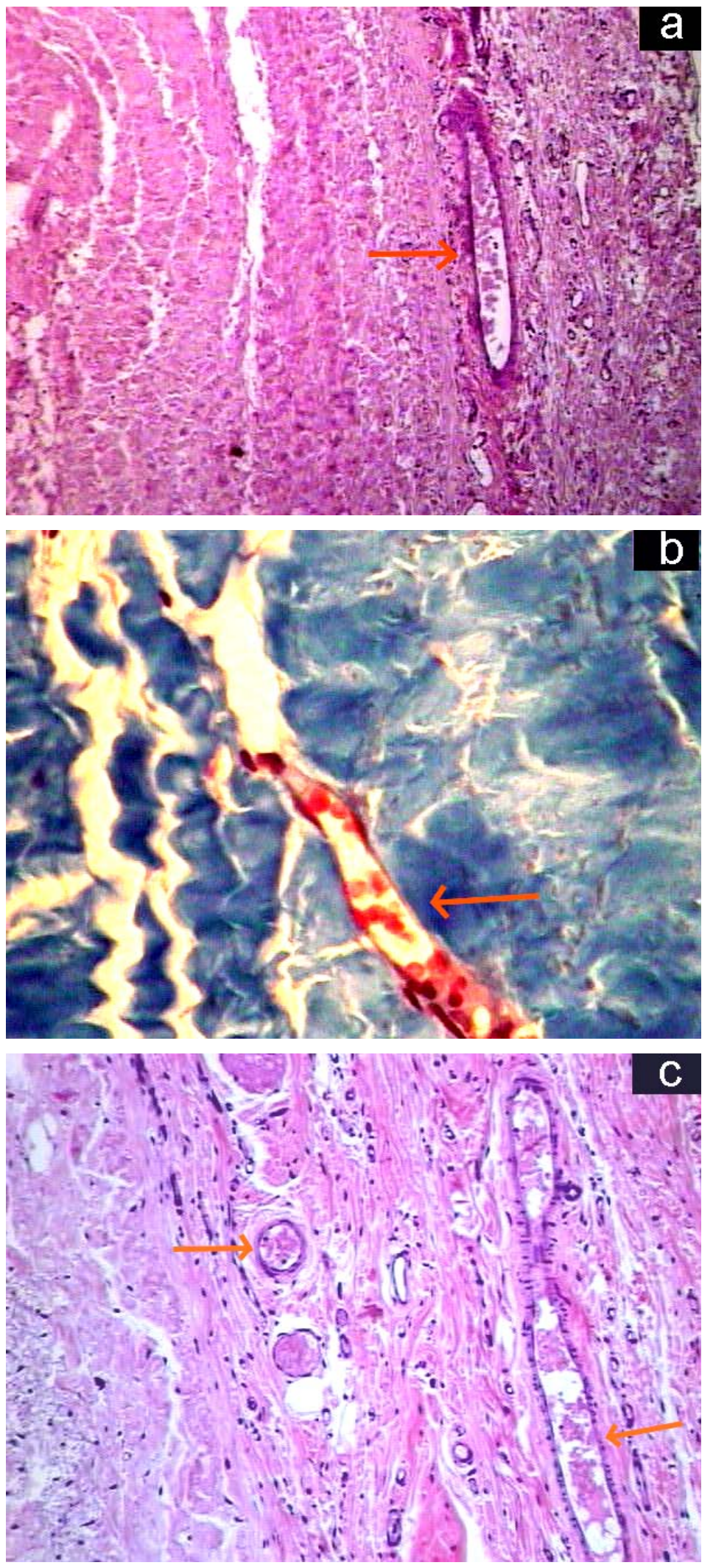

Figura 17. Micrografias após 120 dias de implante: a - (PB24) artéria de pequeno calibre na região entre o processo de fibrose e o implante (5x), H.E.; b (PB24 + ATB) neoformação vascular na porção profunda do implante (40x), T.M.; c - (PB48) vasos sangüíneos na porção superficial do implante (10x), H.E.; (vasos sangüíneos - setas vermelhas). 
O infiltrado inflamatório apresentou-se com predomínio de linfócitos, não se observando células gigantes. Na região superficial e peri-implante, o processo inflamatório mostrou-se discreto em PB24 e PB48 (0-1+/5), com maior intensidade em PB24 + ATB (2+/5) (figura 18.a). Na porção profunda, houve redução da intensidade do processo inflamatório em PB24 e PB24 + ATB (0-1+/5), o mesmo mantendo-se ausente em PB48 (figura 18.b).

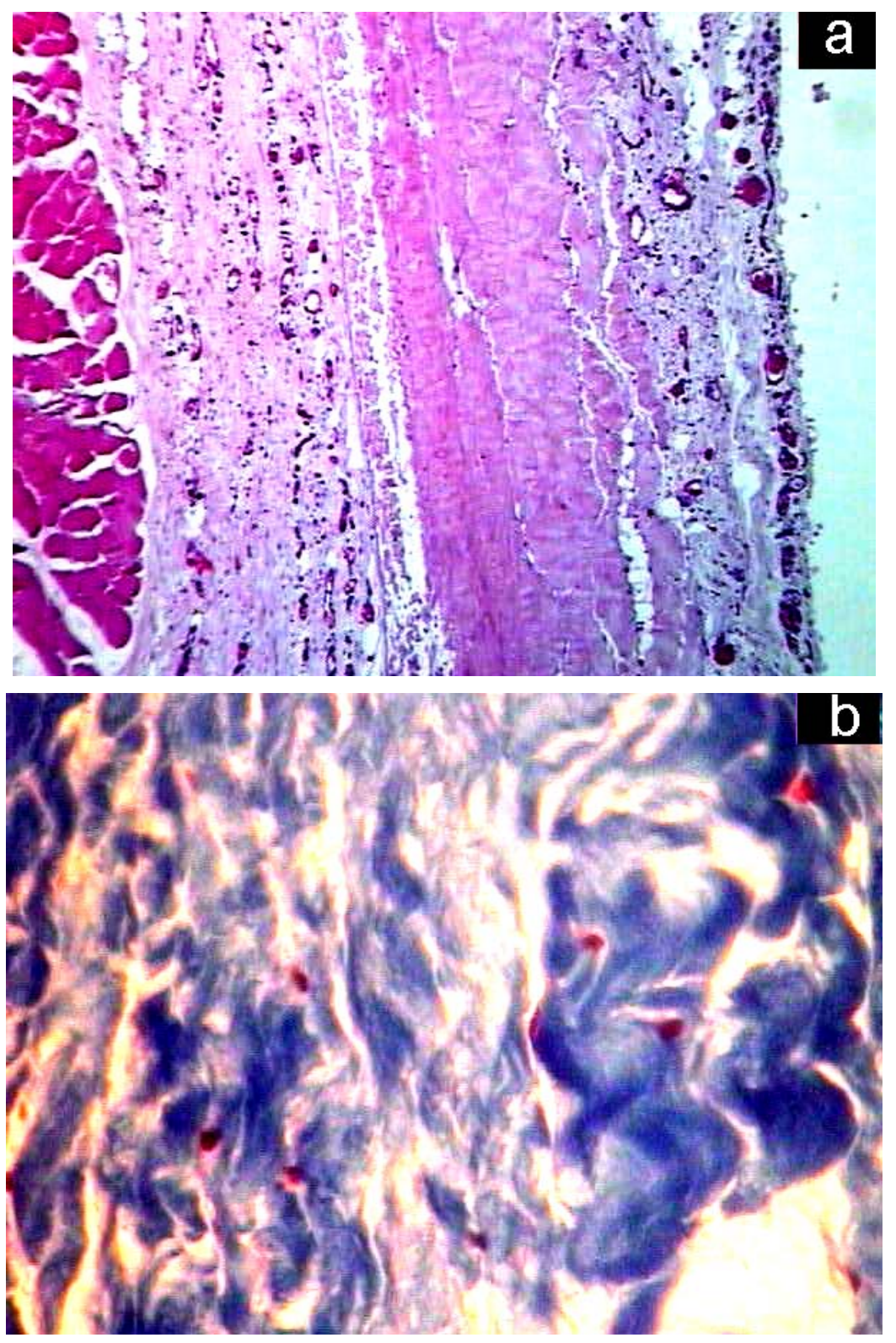

Figura 18. Micrografias após 120 dias de implante: a - (PB24 + ATB) infiltrado inflamatório de 2+/5 na superfície do explante(5x), H.E.; b - (PB48) ausência de processo inflamatório na porção profunda do explante (40x), T.M.. 
Quanto às fibras colágenas, estas apresentaram alterações degenerativas, variando de 1+/5 a 3+/5 nos materiais estudados. Dentre estes, o PB24 foi o material que menos apresentou alteração degenerativa, ou seja, 1+/5 na maioria dos explantes (figura 19.a). Em PB24 + ATB, a maioria de seus explantes apresentou alterações de 3+/5, com coalescimento das fibras colagênicas em imagens de "borramento" das mesmas. Em PB48, observou-se numerosos adipócitos na maioria dos explantes, além de degeneração estromal das fibras colagênicas variando de 2+/5 a 3+/5 (figura 19.b).
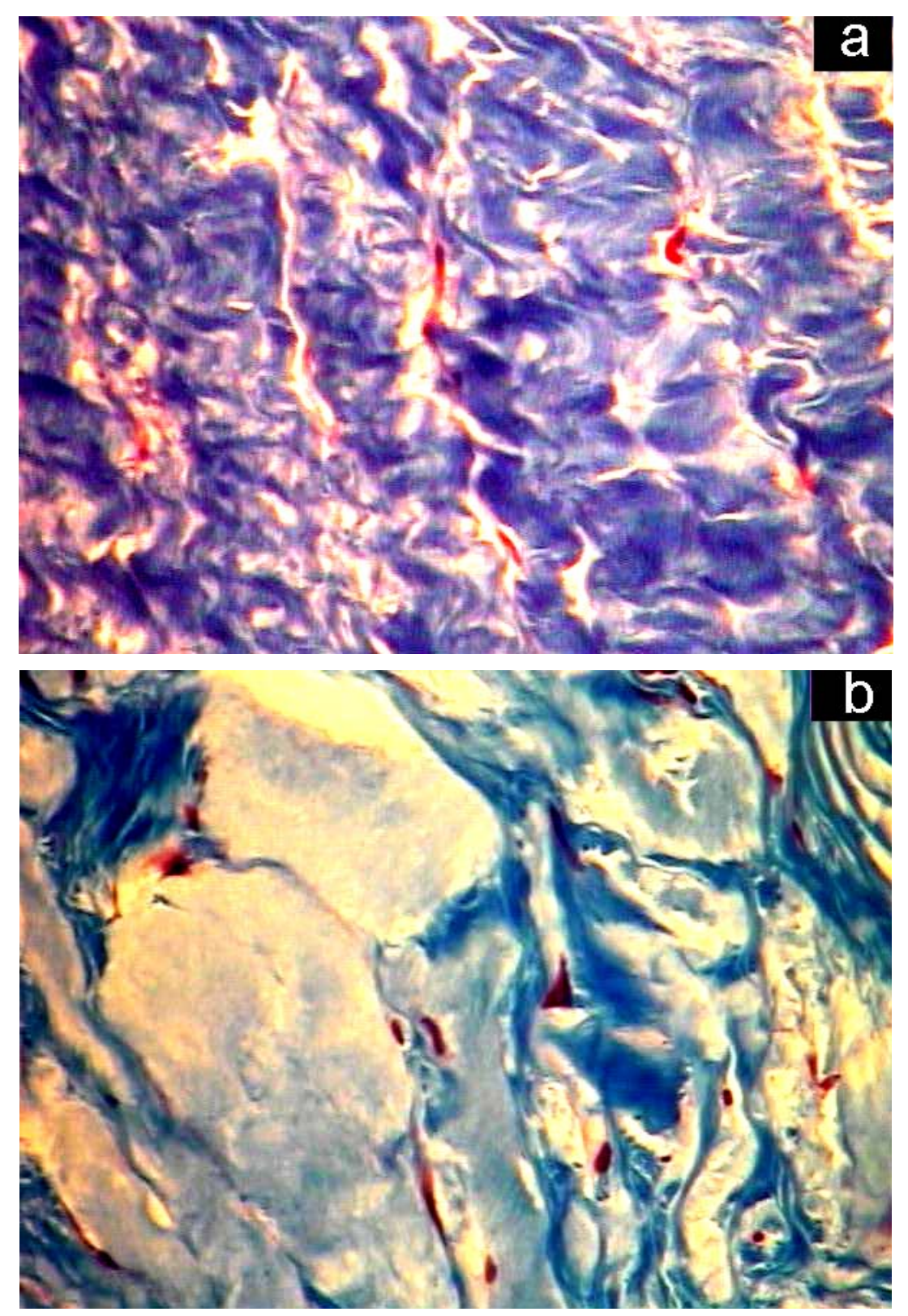

Figura 19. Micrografias após 120 dias de implante: a - (PB24) alteração degenerativa das fibras colágenas em 1+/5 (40x), T.M.; b - (PB24 + ATB) alteração de fibras colágenas em 3+/5 (40x), T.M.. 
A celularidade pós-implante dos materiais foi similar para todos os tempos de tratamento $(2+/ 5)$, observando-se a presença de células fibroblastos "like” por toda extensão dos explantes (figura 20).

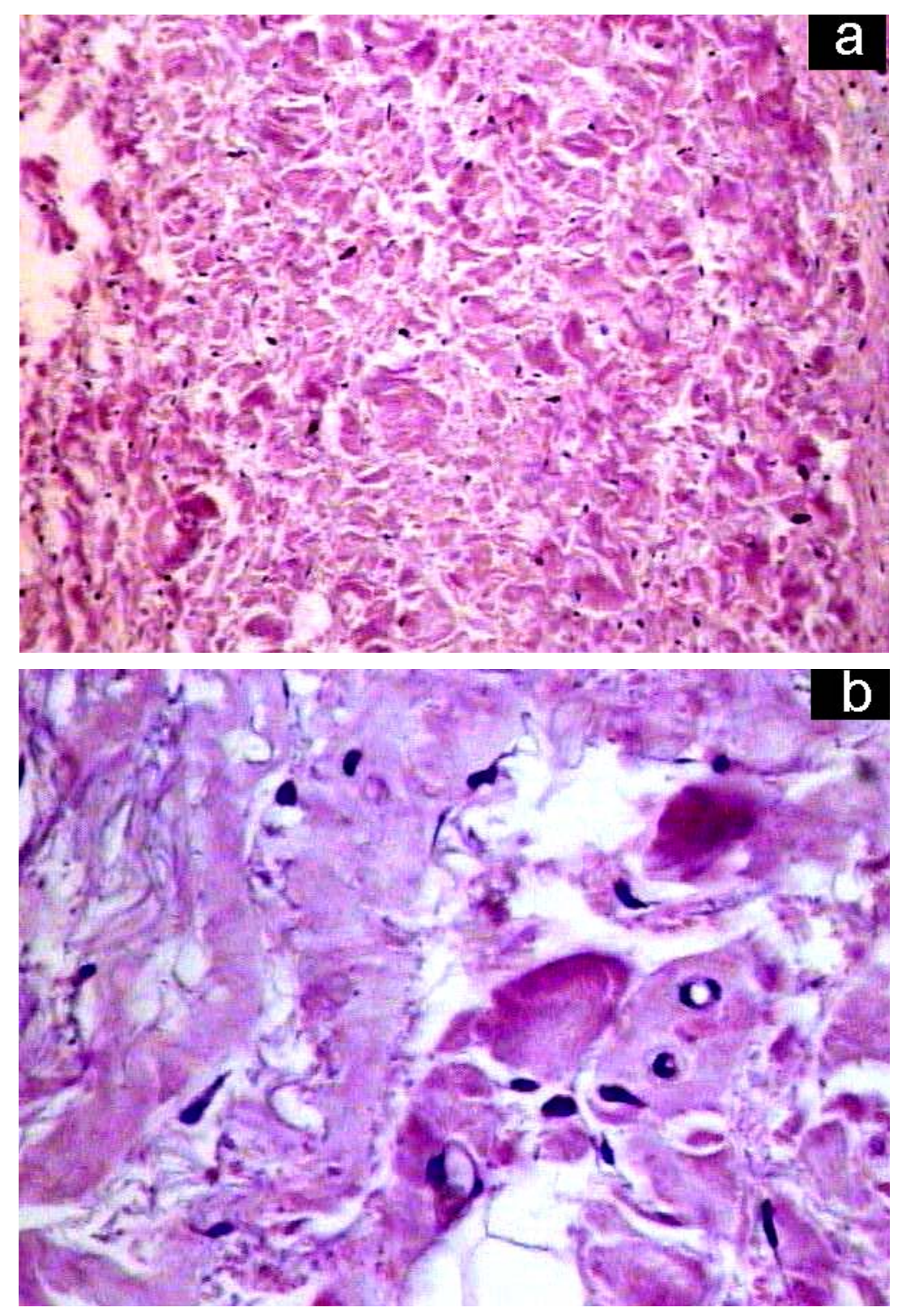

Figura 20. Micrografias após 120 dias de implante: celularidade de $2+/ 5$ na porção interna dos explantes; a - PB24 (10x), H.E.; b - PB48 (40x), T.M..

\section{IV.4.4. Explantes após 180 dias}

A fibrose peri-implante permaneceu semelhante em todos explantes (3+/5), com discreto aumento em PB48. O processo de dissociação das fibras colagênicas pela fibrose peri-implante foi mais uma vez observado em vários explantes de tempos diferentes (figura 21). 
A neoformação vascular mostrou-se com intensidade maior em alguns explantes de PB24 (3+/5), sendo semelhantes nos outros materiais $(2+/ 5)$. Observou-se ainda vasos neoformados na superfície e no interior dos explantes, acompanhando a fibrose peri-implante que dissociava as fibras colagênicas (figura 21).
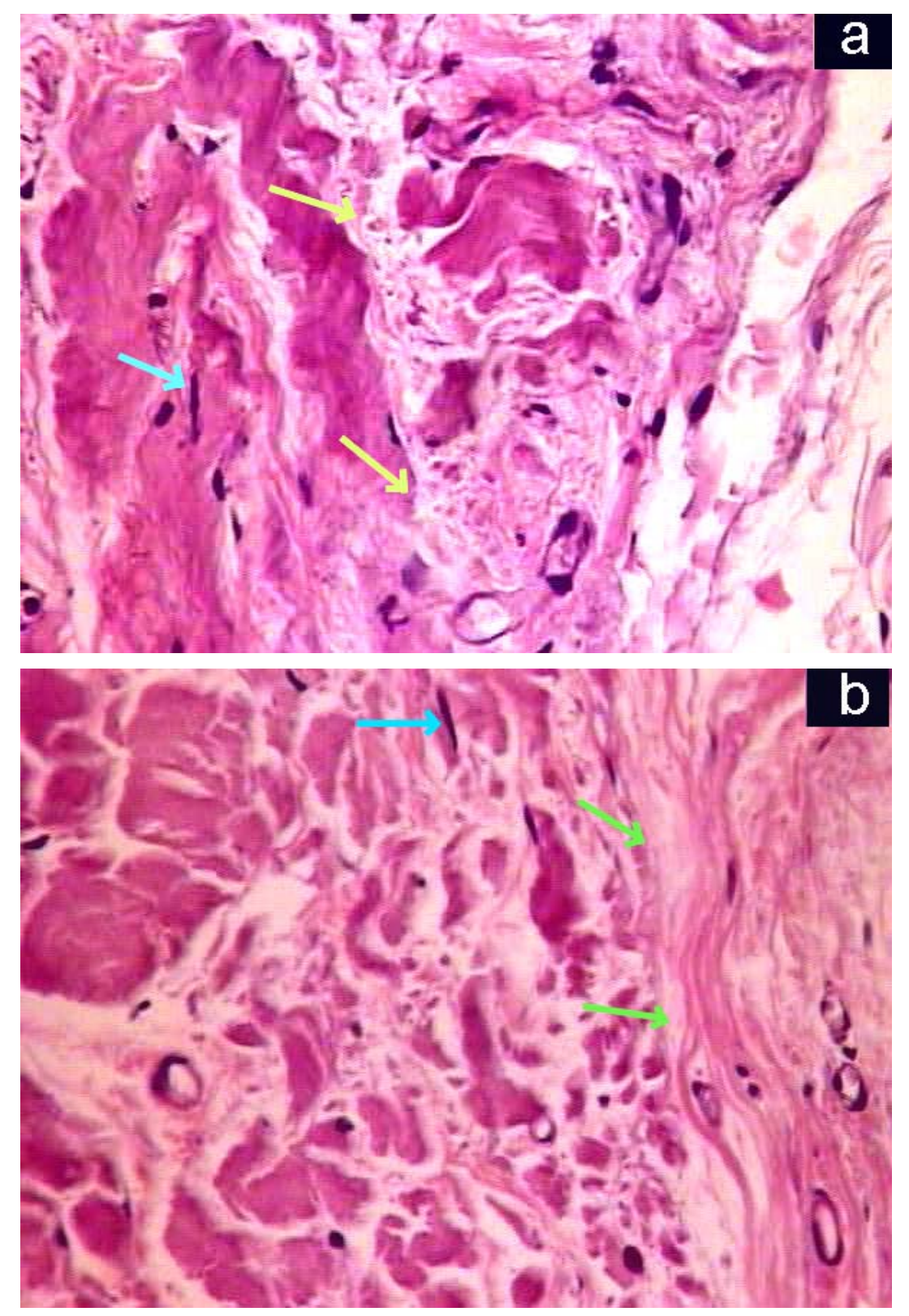

Figura 21. Micrografias após 180 dias de implante: fibrose permeando fibras colagênicas dos explantes (setas verdes) e fibroblastos (setas azuis); a, b PB24 (40x), H.E.. 
O processo inflamatório mostrou-se ausente nas porções superficial e profunda dos explantes (figura 22) e com discreta presença de linfócitos na região peri-implante de PB24 e PB24 + ATB (1+/5). Não foram observadas células gigantes nos explantes.
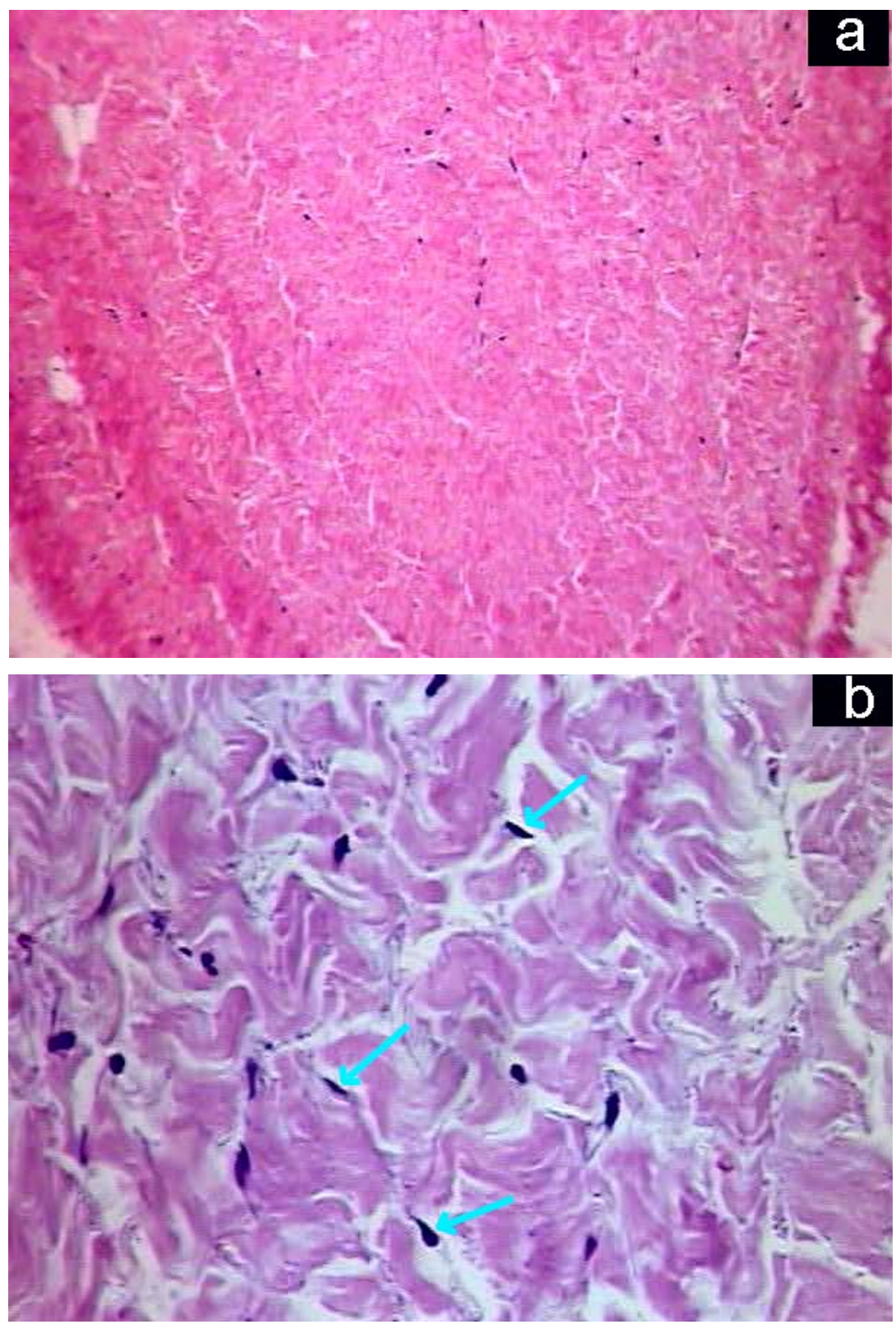

Figura 22. Micrografias após 180 dias de implante: ausência de processo inflamatório nas regiões superficial e profunda dos explantes. Presença de células fibroblasto "like" (setas azuis); a - PB24 + ATB (5x), b - PB48 (40x), H.E.. 
As fibras colagênicas apresentaram alterações degenerativas variáveis nos explantes estudados, com maior intensidade em PB24 + ATB (3+/5) (figura 23.a), sendo de 1+/5 em PB24 (figura 23.b) e PB48.
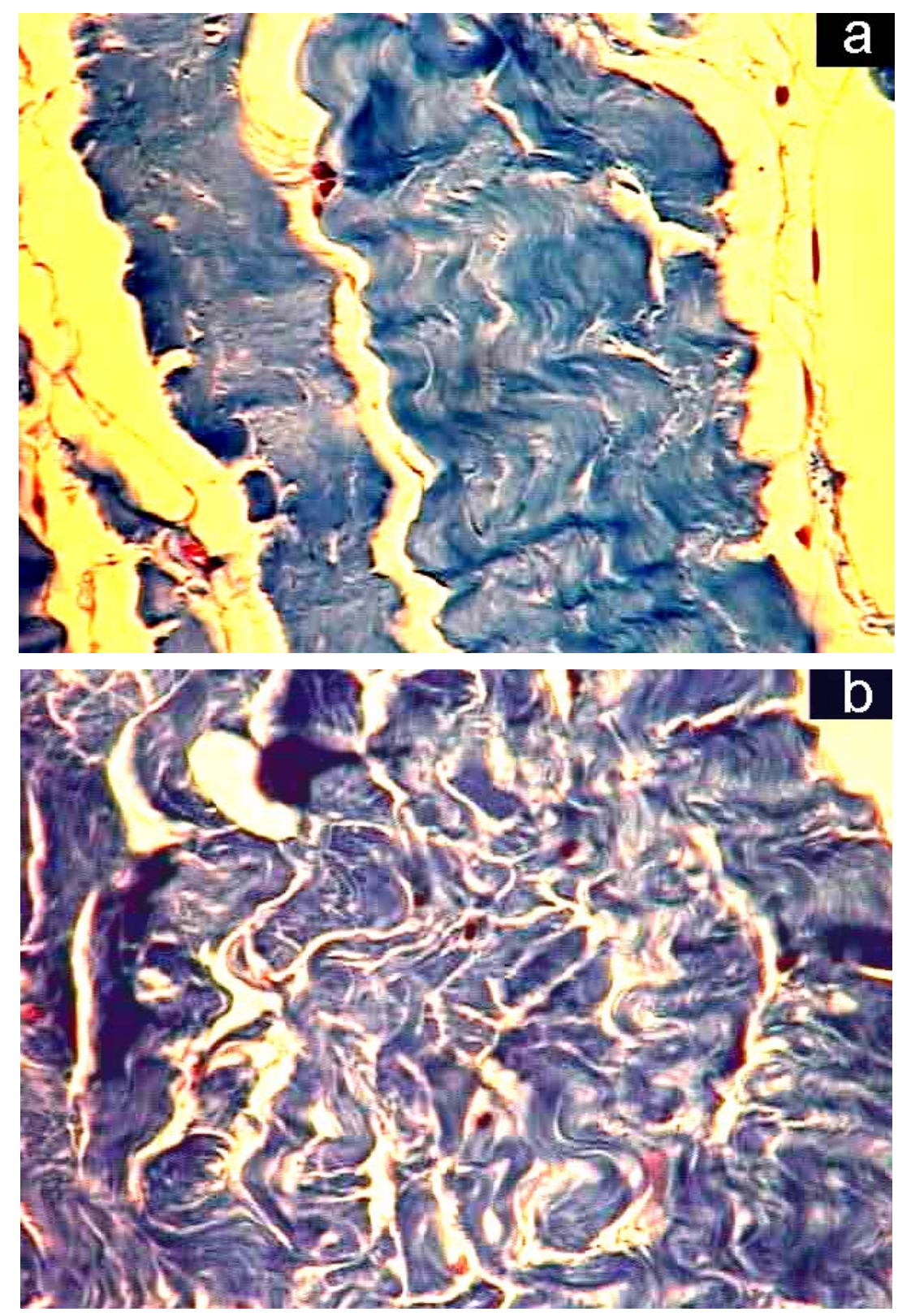

Figura 23. Micrografias após 180 dias de implante: a - (PB24) alteração degenerativa das fibras colágenas em 1+/5 (40x), T.M.; b - (PB24 + ATB) alteração de 3+/5 das fibras colágenas (40x), T.M.. 
Quanto à celularidade pós implante, esta apresentou elevada população de células fibroblastos "like” em alguns explantes, estando tal tipo celular sempre presente no material estudado (figura 24).
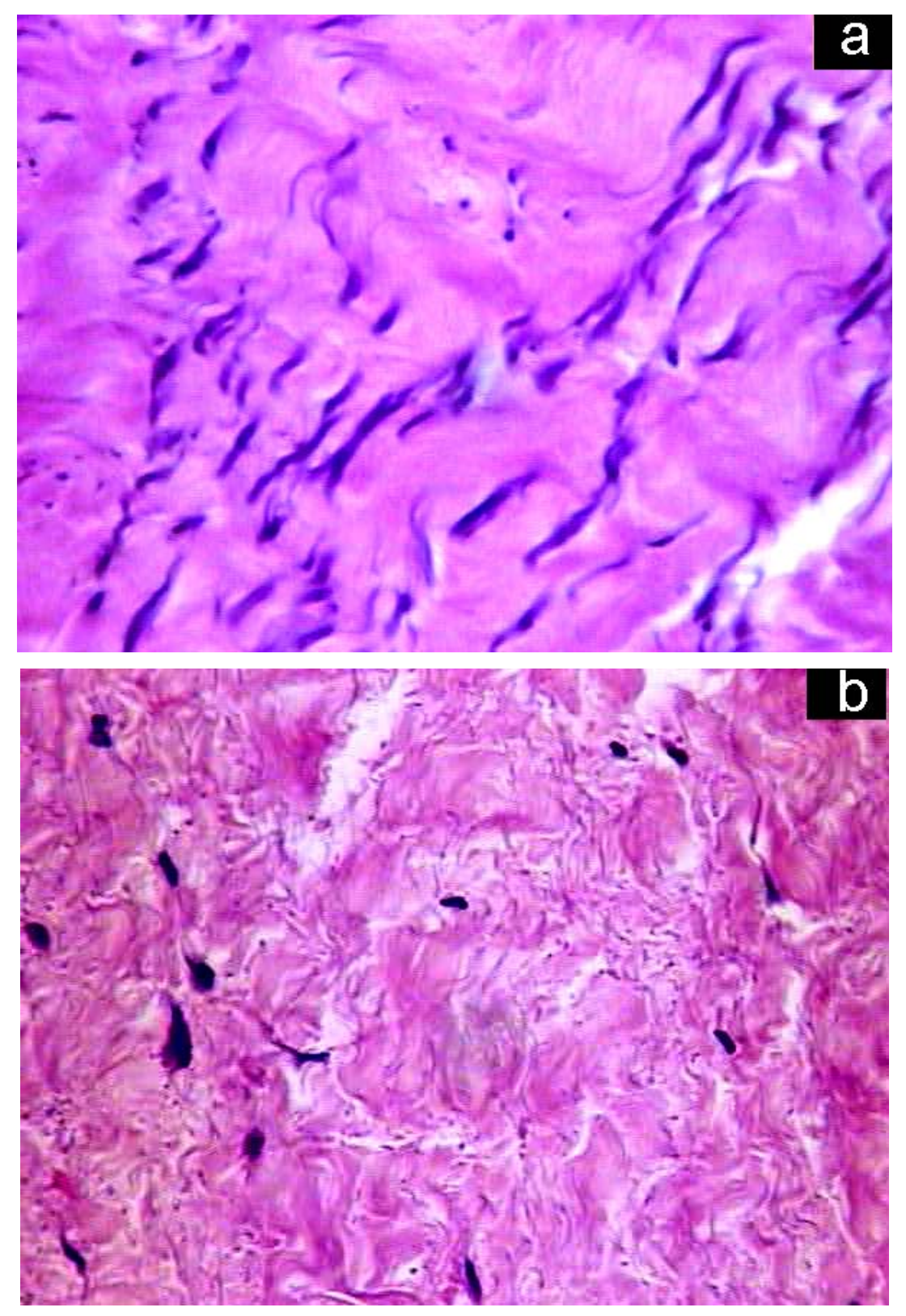

Figura 24. Micrografias após 180 dias de implante: intensa celularidade na porção interna dos explantes representadas por células fibroblastos "like"; a (PB24) (40x), H.E.; b - PB24 + ATB (40x), H.E.. 
Quanto às fibras elásticas, estas foram estudadas a partir da microscopia óptica tendo sido o material corado com Verhoeff. Observou-se que a estrutura fibrilar elástica apresentou aspecto preservado, sem possibilidade de definição quanto as mesmas serem novas ou antigas (figura 25).
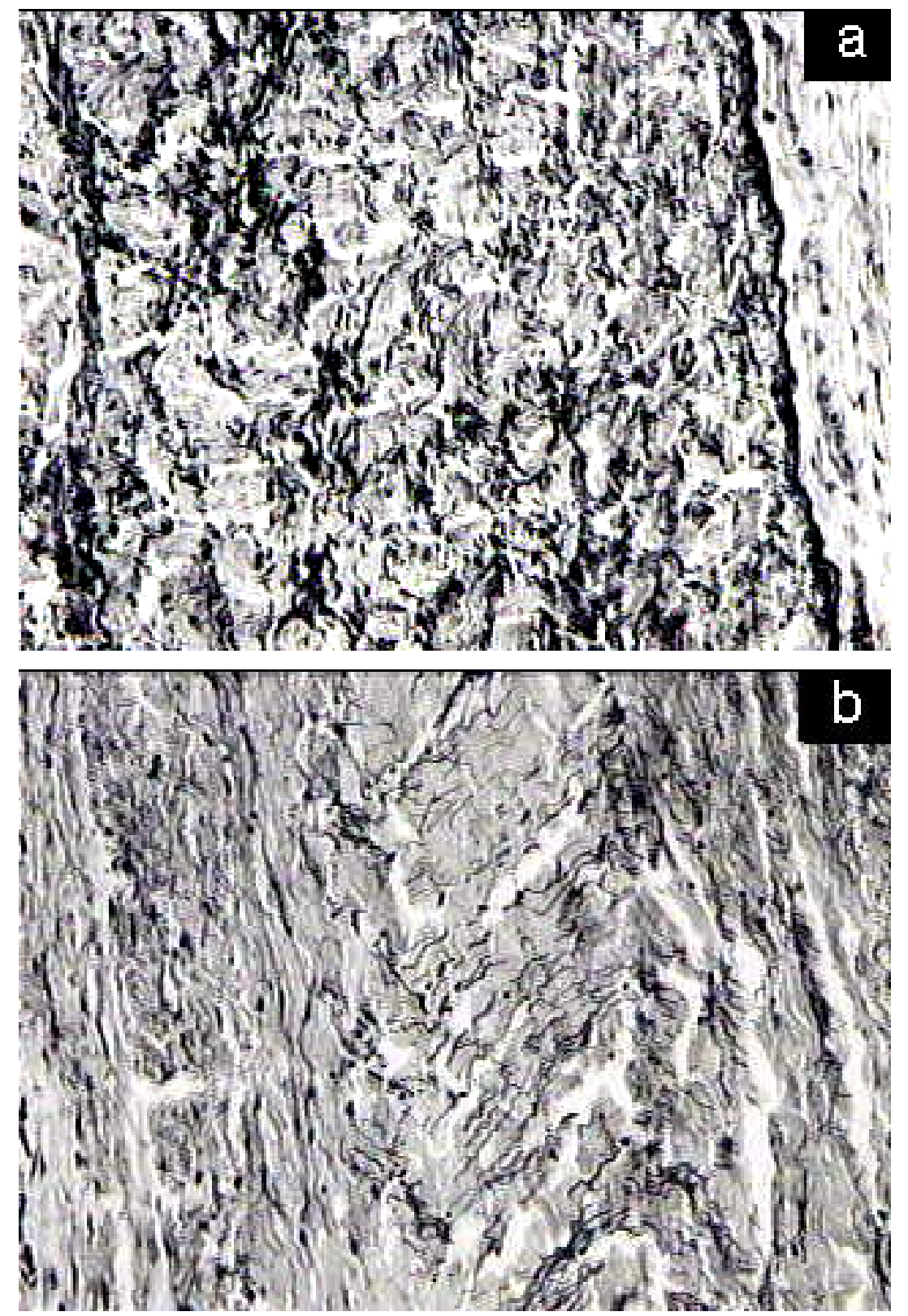

Figura 25. Micrografias após 180 dias de implante: a - (PB24) preservação das fibras elásticas, (40x), Verhoeff.; b - (PB48) alteração 2+/5 das fibras elásticas (40x), Verhoeff. 


\section{DISCUSSÃO}

\section{V.1. Biocompatibilidade}

Após 14 dias, observou-se que o grau de fibrose peri-implante decresceu de intensidade ao longo dos tempos de tratamento químico dos materiais, sendo menos acentuado naqueles de 48 horas. A neoformação vascular mostrou-se semelhante para todos os materiais, seguindo o mesmo padrão observado em experimento anterior (54).

O infiltrado inflamatório mononuclear observado na região extra-pericárdica (na porção mais externa do material) mostrou-se de intensidade moderada nos três materiais estudados, e apresentando concomitante persistência de discreto processo inflamatório agudo inespecífico. Na superfície do material implantado, constatou-se redução do número de células inflamatórias linfocitárias nos implantes tratados por 24 horas, com relação ao pericárdio nativo. Para os materiais tratados por 48 horas, manteve-se resposta inflamatória discreta. No interior dos explantes, não se observou infiltrado inflamatório.

As fibras colágenas mostraram o mesmo grau de alterações degenerativas observadas anteriormente nos materiais tratados por 24 horas. Nos demais materiais, PB24 + ATB e PB48, constatou-se moderadas alterações degenerativas das fibras colágenas, caracterizadas pelo aumento de volume e "borramento" das mesmas. Tais alterações são resultantes do tratamento alcalino sofrido pelo material.

Quando se realiza uma comparação entre os dados obtidos no trabalho anterior (54) e aqueles colhidos neste, observa-se, de maneira geral, uma repetição do padrão histológico nos materiais tratados quimicamente. Nota-se que as células inflamatórias mais presentes nesta fase foram os linfócitos mononucleares, neutrófilos e histiócitos uni e multinucleares, caracterizando um processo inflamatório agudo. No pericárdio nativo (54), notou-se um aumento da reação inflamatória proporcional ao tempo de permanência do mesmo nos hospedeiros (figura 26). A situação inversa ocorreu com o material tratado quimicamente, havendo ainda nesta fase migração de células fibroblastos "like” para o interior do implante e processo de vascularização peri-implante. 

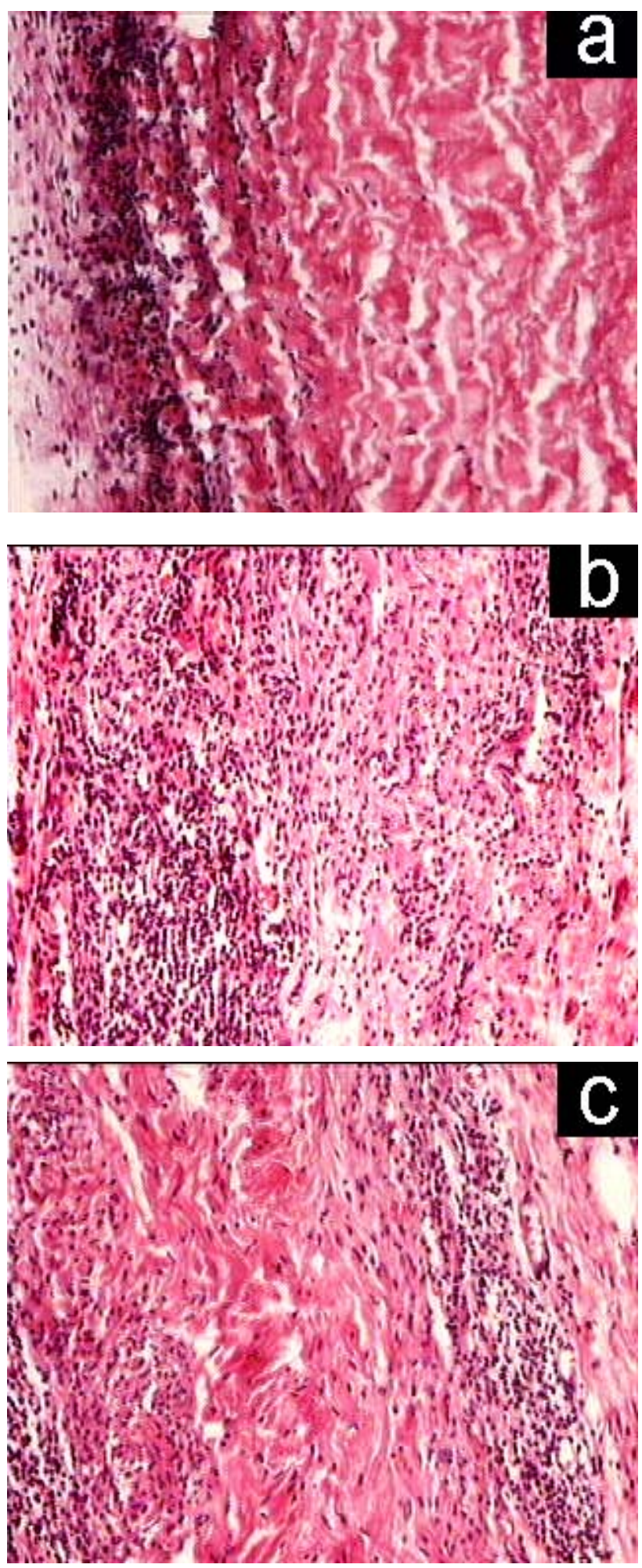

Figura 26. Micrografias de pericárdio nativo: a - 14 dias de implante, mostrando infiltrado inflamatório acentuado na superfície do material 40x, H.E.; b - 28 dias de implante com infiltrado inflamatório em toda extensão do pericárdio 10x, H.E.; c - 74 dias após implante, evidenciando a persistência de infiltrado inflamatório no material. 
Sendo assim, nota-se que o material tratado quimicamente mostrou-se biocompatível, não apresentando processo inflamatório crônico, encapsulamento ou processo de calcificação nos materiais estudados.

\section{V.2. Integração Tissular}

Quanto aos materiais retirados após 60 dias, o grau de fibrose peri-implante mostrou-se menor em todos os casos estudados, comparativamente aos explantes de 14 dias. A neoformação vascular peri-implante permaneceu com índices semelhantes aos materiais de 14 dias.

Houve diminuição de intensidade do processo inflamatório peri-implante nos explantes tratados por 24 horas e com antibiótico, em relação aos explantes de PB24 e PB48. Na superfície do material implantado, a intensidade do infiltrado inflamatório apresentou-se com intensidade discreta. Na porção profunda do material implantado, notouse pequena quantidade de células inflamatórias mononucleares nos explantes de PB24 + ATB e PB48.

Observou-se presença de discretas alterações degenerativas focais nas fibras colágenas em todos os materiais. Quanto à celularidade pós implante, constatou-se similaridade a de estudos feitos anteriormente, havendo a manutenção da quantidade de células fibroblastos “like”.

Em princípio, não se evidenciou pela coloração de H.E. qualquer processo de calcificação tanto dos materiais de 14 dias quanto naqueles de 60 dias.

Após 120 dias, houve um direcionamento do processo de fibrose peri-implante para o interior dos explantes, entre as fibras colagênicas. Juntamente com a fibrose, houve também a progressão de vasos sangüíneos para o interior dos explantes, com aumento de sua presença nas regiões extra e intra-pericárdica.

O processo inflamatório foi caracterizado pelo predomínio de linfócitos, em quantidades semelhantes ou inferiores aos tempos de 14 e 60 dias. Não foram observadas células gigantes. 
As fibras colágenas apresentaram alterações variáveis, sendo mais preservadas em PB24. Houve ainda o aparecimento de adipócitos em PB48, um evento também observado quando do implante do mesmo material em calvária de rato (59). Observamos também que nos materiais antes da implantação não foi detectado qualquer indício da presença deste tipo de célula.

Quanto à celularidade, houve migração de células fibroblasto “like” para o interior dos implantes.

Após 180 dias, a intensidade do processo de fibrose peri-implante permaneceu semelhante ao já visto anteriormente, notando-se novamente a sua progressão entre as fibras de colágeno em direção ao interior dos explantes, juntamente com vasos sanguíneos.

O processo inflamatório apresentou infiltrado linfocítico apenas na região periimplante de PB24 e PB24 + ATB em discreta quantidade (1+/5). Houve redução em relação aos tempos anteriores, estando ausente em PB48.

As fibras colagênicas apresentaram maior alteração da estrutura fibrilar em PB24 + ATB. Observou-se, novamente, adipócitos em explantes de vários tempos. A celularidade mostrou-se mais evidente em alguns explantes, mantendo a população de células fibroblasto "like".

O material estudado apresentou resposta inflamatória crônica de menor intensidade quando comparado ao pericárdio nativo implantado pelo mesmo tempo em estudo anterior (59), não apresentando também processo de encapsulamento do material. Além disso, não houve degradação significativa do material, estando presente de forma quase intacta ao explantá-lo após 180 dias.

Associado a tal fato observou-se que, com o passar do tempo, o processo de fibrose peri-implante direcionou-se ao interior do material (figura 27), acompanhado por neovascularização, que não houve processo inflamatório após tempos prolongados de implante, sem evidências de reação do tipo corpo estranho, e que a celularidade foi evidenciada pela presença de células fibroblastos “like” por toda extensão dos explantes. Assim, o material em estudo está se comportando com os requisitos de uma matriz tridimensional. 

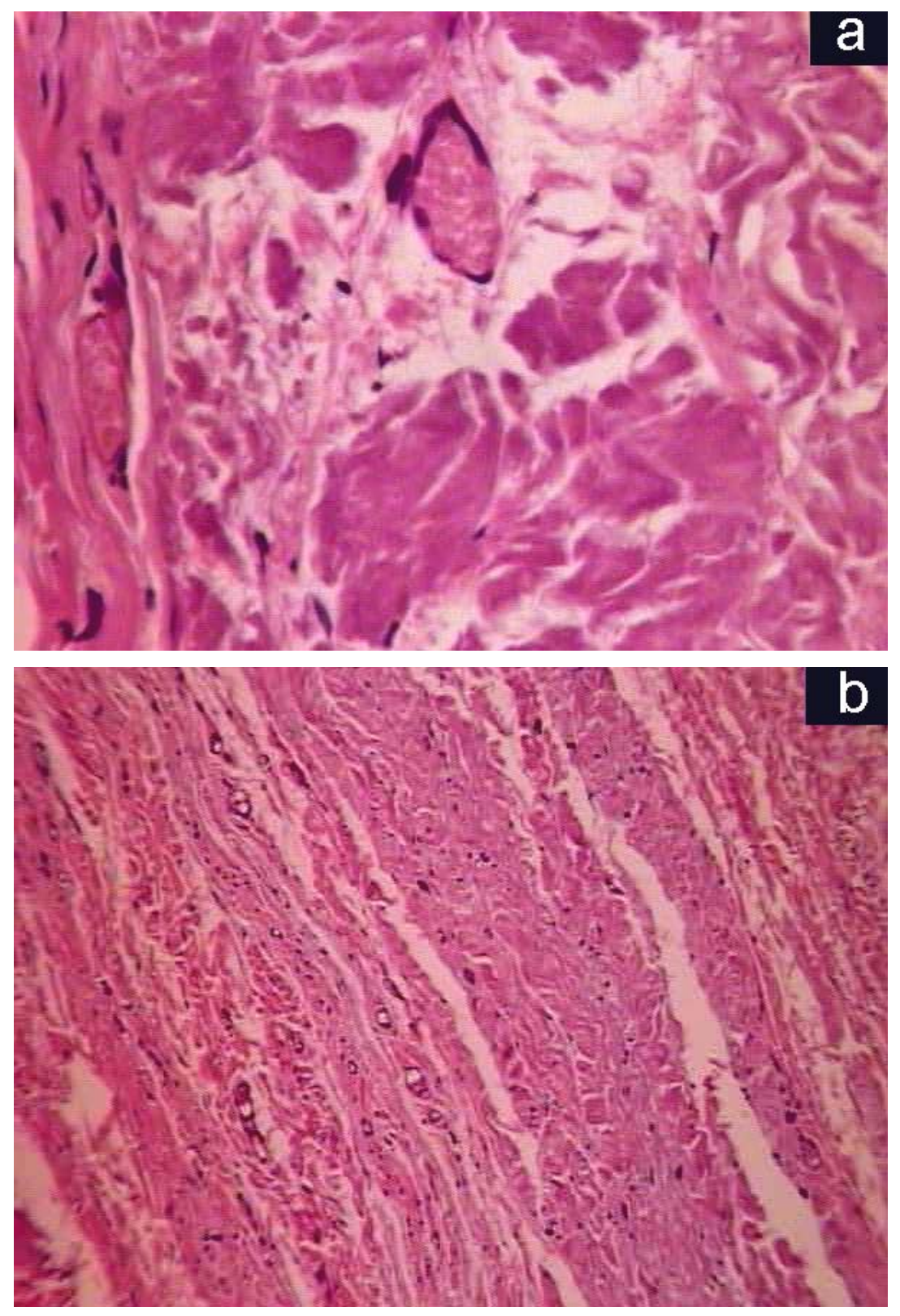

Figura 27. Micrografias após 180 dias de implante: a - (PB24) área de integração em maior aumento 40x, H.E.; b - (PB48) integração do material implantado ao tecido do hospedeiro; área sem delimitação entre implante e subcutâneo do rato $10 x$, H.E. 


\section{CONCLUSÕES}

Como conclusões, pode-se observar que, em geral, não houve processo inflamatório crônico, encapsulamento ou calcificação nos materiais tratados. Observou-se ainda que o tempo de residência do material implantado perdurou após 180 dias, havendo a presença de células fibroblasto “like” em todos explantes, com processo de neovascularização em toda a extensão dos explantes sugerindo a incorporação do material pelo hospedeiro. Tais aspectos sugerem o uso potencial destas matrizes extracelulares na reconstrução de tecidos moles, visto que este material apresenta características que ainda não foram observadas nos materiais disponíveis na atualidade. 


\section{REFERÊNCIAS BIBLIOGRÁFICAS}

[1] DEUEL, T.F. (1997). Introduction in tissue engineering. In: LANZA, R.P.; LANGER, R.; CHICK, W.L. (Ed.). Principles of tissue engineering. San Diego: Academic Press. p.133-149.

[2] LANGER, R.; VACANTI, J.P. (1993). Tissue engineering. Science, Washington, v.260, n.5110, p.920-926, May.

[3] KIM, B.S.; MOONEY, D.J. (1998). Development of biocompatible synthetic extracellular matrices for tissue engineering. Trends in Biotechnology, Cambridge, v.16, n.5, p.224-230, Dec.

[4] FOLKMAN, J.; HAUDENSCHILD, C. (1980). Angiogenesis in vitro. Nature, London, v.288, n.5791, p.551-556, Dec.

[5] WILLIAM, D.F.(1987). Definitions in biomaterials. New York: Elsevier.

[6] SILVER, F.; DOILLON, C. (1989). Biocompatibility: interations and implantable materials. New York: VCH. v.1.

[7] HENCH, L.L.(1998). Biomaterials: a forecast for the future. Biomaterials, Guildford, v.19, n.4/5, p.419-423, Mar.

[8] LANGER, R. et al. (1990). Future directions in biomaterials. Biomaterials, Guidford, v.11, n.9, p.738-745, Nov.

[9] STEVEN, L.; GOODMAN, P.A.S.; ALBRECHT, R.M. (1996). Three-dimensional extracellular matrix textured biomaterials. Biomaterials, Guildford, v.17, n.21, p.20872095, Nov.

[10] MA, P.X.; ZHANG, R. (1999). Synthetic nano-scale fibrous extracellular matrix. Journal of Biomedical Materials Research, New York, v.46, n.1, p.60-72, July.

[11] WILLIAMS, R.L.; DOHERTY, P.J. (1994). A preliminary assessment of poly(pyrrole) in nerve guide studies. Journal of Materials Science: Materials in Medicine, London, v.5, n.6/7, p.429-433, June/July.

[12] FUKADA, E. (1988). Piezoelectricity of natural biomaterials. In: GALLETTI, P.M.; DE ROSSI, D.E.; DE REGGI, A.S. (Ed.). Medical applications of piezoelectric polymers. New York: Gordon and Breach Science. (Ferroelectricity and Related Phenomena, 5). p.15-26.

[13] HUTMACHER, D.W. (2000). Scaffolds in tissue engineering bone and cartilage. Biomaterials, Guildford, v.21, n.24, p.2529-2543, Dec. 
[14] ATHANASIOU, K.A.; NIEDERAUER, G.G.; AGRAWAL, C.M. (1996). Sterilization, toxicity, biocompatibility and clinical applications of polylactic acid/polyglycolic acid copolymers. Biomaterials, Guildford, v.17, n.2, p.93-102, Jan.

[15] PIEPER, J.S.et al. (2000). Attachment of glycosaminoglycans to collagenous matrices modulates the tissue response in rats. Biomaterials, Guildford, v.21, n.16, p.16891699, Aug.

[16] YE, O.; GREGOR, J.S.; HOERSTRUP, S.P. (2000). Tissue engineering in cardiovascular surgery: new approach to develop completely human autologous tissue. European Journal of Cardio-Thoracic Surgery, Amsterdam, v.17, n.4, p.449-454, Apr.

[17] MANN, B.K. et al. (1999). Modification of surfaces with cell adhesion peptides alters extracellular matrix deposition. Biomaterials, Guildford, v.20, n.23/24, p.2281-2286, Dec.

[18] ALBERTS, B. et al. (1994). Molecular biology of the cell. $3^{\text {rd }}$ ed. New York: Garland. p.971-95.

[19] HOFFMAN, A.S. (1995). Intelligent polymers in medicine and biotechnology. Artificial Organs, Cleveland, v.19, n.5, p.458-467, May.

[20] MARK, J.E.; CALVERT, P.D. (1994). Biomimetic, hybrid and in situ composites. Materials Science and Engineering: C, Lousanne, v.1, n.3, p.159-173, Apr.

[21] MATSUI, S. (1996). Histological evaluation of skin reconstruction using artificial dermis. Biomaterials, Guildford, v.17, n.10, p.995-1000.

[22] SAKIEL, S. (1995). Clinical application of new bovine collagen membranes as a partial-thickness burn wound dressing. Polimery w Medycynie, Wroclaw, v.25, n.3/4, p.19-24.

[23] BLACKSHAW, S.E. et al. (1997). Promotion of regeneration and axon growth following injury in an invertebrate nervous system by the use of three-dimensional collagen gels. Proceedings of the Royal Society of London Series B - Biological Sciences, London, v.264, n.1382, p.657-661, May.

[24] ANTISZKO, M. et al. (1995). A comparative examination of the homeostatic properties of xenogenic collagenic biomaterials. Polimery w Medycynie, Wroclaw, v.25, n.3/4, p.37-45.

[25] RAO, K.P. (1995). Recent developments of collagen-based materials for medical applications and drug delivery systems. Journal of Biomaterials Science Polymer Edition, Zeist, v.7, n.7, p.623-645.

[26] REID, G.G.; GORHAM, S.D.; LACKIE, J.M. (1993). The attachment, spreading and growth of baby hamster kidney cells on collagen, chemically modified collagen- 
composite substrata. Journal of Materials Science: Materials in Medicine, London, v.4, n.2, p.201-209, Mar.

[27] SHENOY, V.; ROSEMBLATT, J. (1995). Diffusion of macromolecules in collagen and in hyaluronic acid, rigid-rod-flexible polymers, composite matrices. Macromolecules, Washington, v.28, n.26, p.8751-8758, Dec.

[28] HU, X.W.; KNIGHT, D.P.; GRANT, R.A. (1996). The effect of deamination and/or blocking of arginine residues on the molecular assembly of acid extract rat tail tendon collagen. Tissue Cell \& Research, Harlow Essex, v.28, n.2, p.215-222, Apr.

[29] PLEPIS, A.M.G.; GOISSIS, G.; DAS-GUPTA, D.K. (1996). Dielectric and pyroelectric characterization of anionic and native collagen. Polymer Engineering and Science, Easton, v.36, n.24, p.2932-2938, Dec.

[30] LACERDA, C.A. (1997). Preparação e caracterização de colágeno aniônico para utilização como biomaterial. 57p. Dissertação (Mestrado) - Instituto de Química de São Carlos, Universidade de São Paulo, São Carlos. 1997.

[31] SCHMIDT, C.E., BAIER, J.M. (2000). Acellular vascular tissues: natural biomaterials for tissue repair and tissue engineering. Biomaterials, Guildford, v.21, n.22, p.2215-2231, Nov.

[32] GOISSIS, G. et al. (2000). Preparation and caracterization of collagen: elastin matrices from blood vessels intended as small diameter vascular grafts. Artificial Organs, Cleveland, v.24, n.3, p.217-223, Mar.

[33] PROBST, M. et al. (1997). Reproduction of functional smooth muscle tissue and partial bladder replacement. Britich Journal of Urology, London, v.79, n.4, p.505-515, Apr.

[34] ACHAUER, B.M. et al. (1998). Augmentation of facial soft-tissue defects with alloderm dermal graft. Annals of Plastic Surgery, Philadelphia, v.41, n.5, p.503-507, Nov.

[35] MOONEY, D.J. et al. (1997). Long-term engraftment of hepatocytes transplanted on biodegradable polymer sponges. Journal of Biomedical Materials Research, New York, v.37, n.5, p.413-420, Dec.

[36] GUPTA, B.S.; KASYANOV, V.A. (1997). Biomechanics of human common carotid artery and design of novel hybrid textile compliant vascular grafts. Journal of Biomedical Materials Research, New York, v.34, n.3, p.341-349, Mar.

[37] RATNER, B.D. (1993). New ideas in biomaterials science a path to engineered biomaterials. Journal of Biomedical Materials Research, New York, v.27, n.7, p.837850, July. 
[38] VOGLER, E.A. et al. (1995). Contact activation of the plasma coagulation cascade.I. Procoagulant surface chemistry and energy. Journal of Biomedical Materials Research, New York, v.29, n.8, p.1005-1016, Aug.

[39] VOGLER, E.A. et al. (1995). Contact activation of the plasma coagulation cascade.II. Protein adsorption to procoagulant surfaces. Journal of Biomedical Materials Research, New York, v.29, n.8, p.1017-1028, Aug.

[40] LOPES, M.A. et al. (1999). Hydrophobicity, surface tension, and zeta potential measurements of glass-reinforced hydroxyapatite composites. Journal of Biomedical Materials Research, New York, v.45, n.4, p.370-375, June.

[41] SCHOR, S.L.; COURT, J. (1979). Different mechanisms the attachment of cells to native and denatured collagen. Journal of Cell Science, London, v.38, p.267-281, Aug.

[42] ELLIS, D.L.; YANNAS, I.V. (1996). Recent advances in tissue synthesis in vivo by use of collagen-glycosaminoglycan copolymers. Biomaterials, Guildford, v.17, n.3, p.291-299.

[43] POLLACK, S.R. (1984). Bioelectrical properties of bone. In: BRIGTHON C.T. (Ed.). The orthopedic clinics of North America. Pennsylvania: WBDaunders. v.15, p.3-14.

[44] ADAM, B.; ALAIN, R.; ADRIEN, C. (1997). Vascular endothelial cell responses to different electrically charged poly (vinylidene fluoride) supports under static and oscillating flow conditions. Biomaterials, Guildford, v.18, 2, p.107-112, Jan.

[45] SHELTON, R.M.; DAVIES, J.E. (1991). Osteoblast reactions to charged polymers. In: DAVIES, J.E. (Ed.). The bone - biomaterial interface. Toronto: University of Toronto Press. Cap.9, p.181-198.

[46] KRUKOWSKI, M. (1991). Hard and soft connective tissue growth and repair in response to charged surfaces. In: DAVIES, J.E. (Ed.). The bone - biomaterial interface. Toronto: University of Toronto Press. Cap.25, p.275-284.

[47] HUMPHREY, J.S. et al. (1998). Pharmacokinetics of a degradable drug delivery system in bone. Clinical Orthopaedics and Related Research, Philadelphia, v.1, n.349, p.218-224, Apr.

[48] GRIFFITH, L.G. (2000). Polymeric biomaterials. Acta Materialia, Oxford, v.48, n.1, p.263-277, Jan.

[49] CIRELLI, J.A. et al. (1997). Evaluation of anionic collagen membranes in the treatment of class II furcation lesions: an histometric analysis in dogs. Biomaterials, Guildford, v.18, n.18, p.1227-1234, Sept. 
[50] GOISSIS, G. et al. (1999). Biocompatibility studies of anionic collagen membranes with different degree of glutaraldehyde cross-linking. Biomaterials, Guildford, v.20, n.1, p.27-34, Jan.

[51] GOISSIS, G. et al. (1998). The controlled release of antibiotic by hydroxyapatite:anionic collagen composites. Artificial Organs, Cleveland, v.22, n.3, p.203-209, Mar.

[52] ROSETTI, E.P. et al. (2000). Treatment of gingival recession: comparative study between connective tissue graft and guided tissue regeneration. Journal of Periodontology, Chicago, v.71, n.9, p.1441-1447, Sept.

[53] ROCHA, L.B.; GOISSIS, G.; ROSSI, M.A. (2001). Anionic collagen matrix as scaffold for bone healing. Biomaterials, Guildford, v.23, n.2, p.449-456, Jan.

[54] GOISSIS, G.; SUZIGAN, S.; PARREIRA,D.R. (2000). Matrizes tridimensionais acelularizadas de colágeno: elastina a partir de tecidos: preparação, caracterização e biocompatibilidade. In: CONGRESSO BRASILEIRO DE ENGENHARIA BIOMÉDICA, 17., 2000, Florianópolis. Anais... Florianópolis: [s.n]. p.242-247.

[55] RAMACHANDRAN, G.N. (Ed.). (1967). Treatise on collagen. London: Academic Press. v.1, p.337-353.

[56] BET, M.R.; GOISSIS, G.; LACERDA, C.A. (2001). Characterization of polyanic collagen prepared by selective hydrolysis of asparagine and glutamine carboxyamide side chains. Biomacromolecules, Washington, v.2, n.4, p.1074-1079, Winter.

[57] SOUSA, M.H. (2001). Preparação e caracterização de matrizes de colágeno como suporte de crescimento de tecidos e liberação controlada de antibióticos. 106p. Tese (Doutorado) - Instituto de Química de São Carlos, Universidade de São Paulo, São Carlos. 2001.

[58] PETITE, H. et al. (1995). Cytocompatibility of calf pericardium treated by glutaraldehyde and by the acyl azide methods in a organotypic culture model. Biomaterials, Guildford, v.16, n.13, p.1003-1008, Sept.

[59] ROSA, F.P. et al. (2003). Tissue response polyanionic collagen:elastin matrices implanted in rat calvaria. Biomaterials, Guildford, v.24, n.2, p.207-212, Jan. 